\title{
AVALIAÇÃO DA QUALIDADE MICROBIOLÓGICA DE AMOSTRAS DE MERCADO DE QUEIJO MUSSARELA, ELABORADO A PARTIR DE LEITE DE BÚFALA (Bubalus bubalis)
}

\author{
DÉBORA DE AZEVEDO OLIVIERI
}

\begin{abstract}
Dissertação apresentada à Escola Superior de Agricultura "Luiz de Queiroz", Universidade de São Paulo, para obtenção do título de Mestre em Ciências, Área de Concentração: Ciência e Tecnologia de Alimentos.
\end{abstract}

\author{
P I R A C I C A B A \\ Estado de São Paulo - Brasil
}

Abril - 2004 


\title{
AVALIAÇÃO DA QUALIDADE MICROBIOLÓGICA DE AMOSTRAS DE MERCADO DE QUEIJO MUSSARELA, ELABORADO A PARTIR DE LEITE DE BÚFALA (Bubalus bubalis)
}

\author{
DÉBORA DE AZEVEDO OLIVIERI \\ Engenheiro Agrônomo
}

\author{
Orientador: Prof. Dr. CLÁUDIO ROSA GALLO
}

\begin{abstract}
Dissertação apresentada à Escola Superior de Agricultura "Luiz de Queiroz", Universidade de São Paulo, para obtenção do título de Mestre em Ciências, Área de Concentração: Ciência e Tecnologia de Alimentos.
\end{abstract}

\author{
P I R A C I C A B A \\ Estado de São Paulo - Brasil
}

Abril - 2004 


\section{Dados Internacionais de Catalogação na Publicação (CIP) DIVISÃO DE BIBLIOTECA E DOCUMENTAÇÃO - ESALQ/USP}

Olivieri, Débora de Azevedo

Avaliação da qualidade microbiológica de amostras de mercado de queijo mussarela, elaborado a partir de leite de búfala (Bubalus bubalis) / Débora de Azevedo Olivieri. - - Piracicaba, 2004.

$61 \mathrm{p}$.

Dissertação (mestrado) - - Escola Superior de Agricultura Luiz de Queiroz, 2004.

Bibliografia.

1. Comércio varejista 2. Leite de búfala 3. Microbiologia de alimento 4. Microrganis- $m$ patogênico 5. Queijo mussarela I. Título

CDD 637.353

"Permitida a cópia total ou parcial deste documento, desde que citada a fonte - O autor" 
AOS MEUS AMADOS PAIS, ANGELO (IN MEMORIAM) E ZOÉ, IRMÃS, GRAZIELA E THAIS, E TIA FANNY... 


\section{AGRADECIMENTOS}

- Ao Professor Dr. Cláudio Rosa Gallo, pela orientação, pelos ensinamentos e por toda atenção dedicada a este trabalho;

- Aos Professores Dr. Ernani Porto, Dra. Marta Helena F. Spoto e Dra. Tais Helena Martins Lacerda, pelas sugestões apresentadas;

- Às técnicas do laboratório de Microbiologia de Alimentos, Rose Ocangne, Denise A. L. Baptista e Cecília Nogueira, pela contribuição durante a execução do trabalho prático;

- Às bibliotecárias Beatriz Giongo e Midiam Gustinelli, pela dedicação com que auxiliaram na biblioteca;

- À bibliotecária Ligiana Clemente, pelo auxílio nas correções das referências bibliográficas;

- À secretária da Pós-graduação, Regina Lourenço, por toda ajuda, sempre que necessária;

- À CAPES, pela concessão da bolsa de estudo;

- Aos colegas da Pós-graduação, pelos momentos felizes compartilhados; 
- Aos meus queridos familiares, pelo incentivo constante e apoio nos momentos difíceis. Especialmente à minha mãe, pelo exemplo de força e persistência, e ao meu pai, pelo amor e dedicação e pelo incentivo na etapa inicial deste trabalho. Deixo-Ihes, aqui, o meu profundo respeito e a minha eterna gratidão;

- E a todos que, de alguma forma, contribuíram para a realização deste trabalho. 


\section{SUMÁRIO}

Página

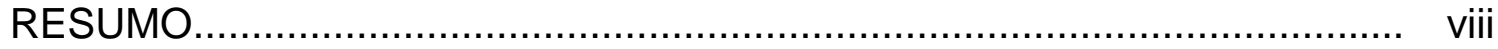

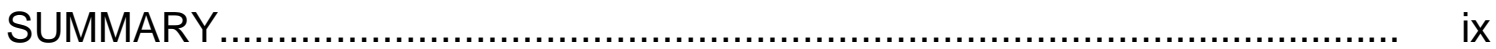

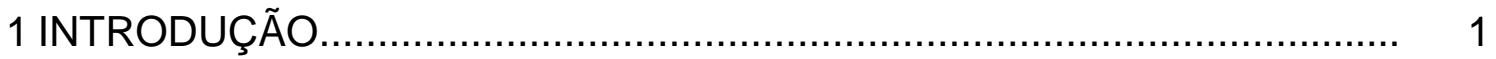

2 REVISÃO DE LITERATURA ......................................................... 3

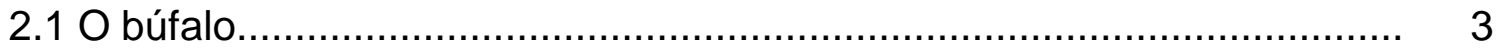

$2.2 \mathrm{O}$ leite de búfala e seus derivados....................................................... 4

2.3 Características da mussarela de leite de búfala................................... 7

2.4 Obtenção higiênica da mussarela de leite de búfala............................. 10

2.5 Padrões microbiológicos para a mussarela de leite de búfala................. 19

3 MATERIAL E MÉTODOS................................................................... 21

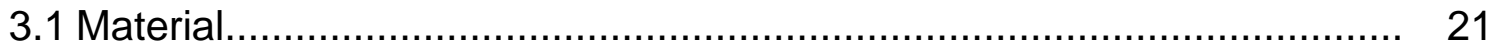

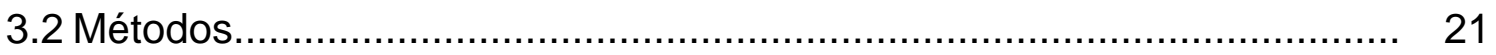

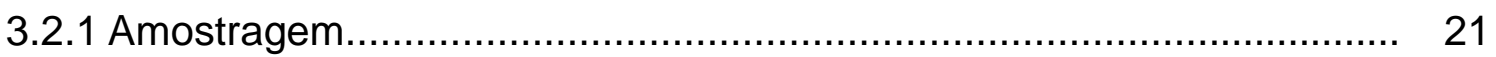

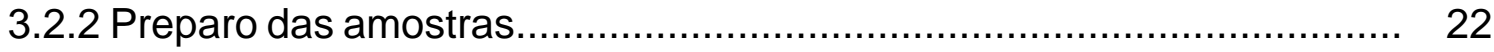

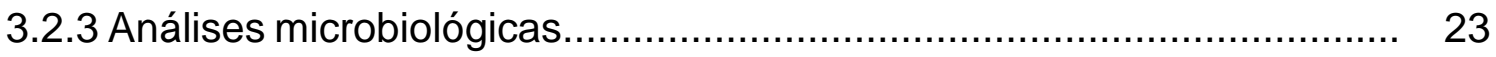

3.2.3.1 Determinação do NMP de coliformes totais e fecais........................ 23

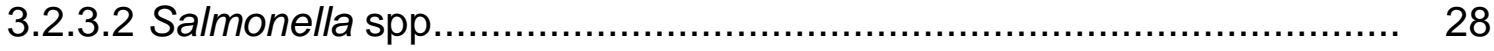

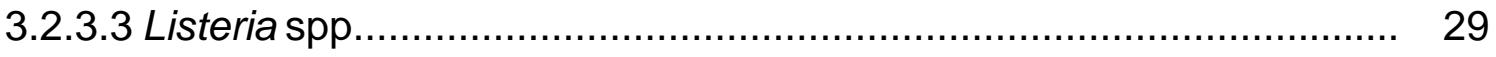

3.2.3.4 Staphylococcus coagulase-positiva............................................. 31

3.2.3.4.1 Teste de coagulase .......................................................... 32

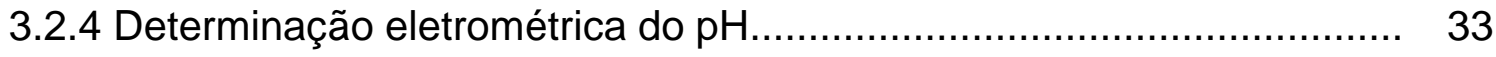

4 RESULTADOS E DISCUSSÃO............................................................... 35 


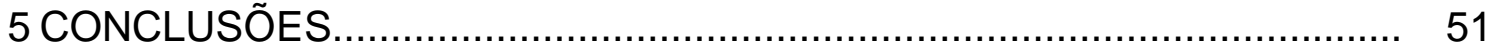

REFERÊNCIAS BIBLIOGRÁFICAS ......................................... 52 


\title{
AVALIAÇÃO DA QUALIDADE MICROBIOLÓGICA DE AMOSTRAS DE MERCADO DE QUEIJO MUSSARELA, ELABORADO A PARTIR DE LEITE DE BÚFALA (Bubalus bubalis)
}

\author{
Autora: DÉBORA DE AZEVEDO OLIVIERI \\ Orientador: Prof. Dr. CLÁUDIO ROSA GALLO
}

\section{RESUMO}

A mussarela de leite de búfala, principal queijo obtido a partir desse leite no Brasil, é um produto praticamente novo no mercado, com alta aceitação pelos consumidores e excelentes perspectivas. Seguindo tecnologia de produção tradicional italiana, caracteriza-se pela intensa manipulação durante a sua elaboração. No presente trabalho, avaliou-se a qualidade microbiológica de duas marcas comerciais de queijo mussarela de leite de búfala, sendo uma das marcas comercializada em embalagem com soro $(A)$ e a outra em embalagem sem soro e a vácuo (B), adquiridas no comércio varejista da cidade de Piracicaba/SP. As análises microbiológicas compreenderam a determinação do NMP de coliformes totais e fecais, a pesquisa de Listeria spp., a contagem de Staphylococcus coagulase-positiva e a pesquisa de Salmonella spp. Com base nos resultados obtidos, pode-se afirmar que as duas marcas analisadas encontram-se em acordo com os padrões microbiológicos legais vigentes. No entanto, pôde-se notar que a qualidade microbiológica dos queijos comercializados em embalagem com soro mostrou-se inferior à dos oferecidos ao consumo em embalagem sem soro e a vácuo. 


\title{
EVALUATION OF THE MICROBIOLOGY QUALITY OF MOZZARELLA CHEESE, PRODUCED WITH MILK OF BUFFALO (Bubalus bubalis) AND ACQUIRED IN THE MARKET
}

\author{
Author: DÉBORA DE AZEVEDO OLIVIERI \\ Adviser: Prof. Dr. CLÁUDIO ROSA GALLO
}

\section{SUMMARY}

Buffalo mozzarella cheese, main cheese obtained from buffalo milk in Brazil, is practically a recent product in the market, showing high acceptance by consumers and excellent perspectives. Following traditional italian production tecnology, this cheese is intensely manipulated during its manufacture. In this study, the microbiology quality of two commercial brands of buffalo mozzarella cheese was evaluated, being one of the brands presented in bag with whey (A) while the other one is presented in bag without whey and under vacuum (B). The samples were acquired in the Piracicaba city commerce. Microbiology analysis comprehended the determination of the MPN of total and fecal coliforms, the Listeria spp. presence / absence, the coagulase-positive Staphylococcus accounting and the Salmonella spp. presence / absence. Based on the analysis results, both brands are according to current legal microbiology standards specifications. However, the microbiology quality of the cheeses packed in bag with whey was lower than the microbiology quality of those offered in bag without whey and under vacuum. 


\section{INTRODUÇÃO}

Embora o gado bovino seja o mais representativo na pecuária nacional, tanto para o corte como para a produção de leite, a bubalinocultura vem rapidamente se difundindo em diversas regiões do país. Características como rusticidade, docilidade, resistência, longevidade, precocidade, proliferidade e grande adaptabilidade destacam o búfalo como uma considerável alternativa para a produção de proteína de alta qualidade para a população, seja pela produção de carne como de leite.

$O$ aumento dos rebanhos leiteiros bubalinos confirma o crescente interesse pela exploração do grande potencial leiteiro desses animais, principalmente nos Estados da região Sudeste.

O leite de búfala apresenta maiores teores de gordura, proteína, extrato seco total e alguns minerais, em relação ao leite bovino. Por essa razão, a grande importância desse alimento está na sua transformação em derivados, uma vez que a sua composição peculiar possibilita um alto rendimento industrial.

Encontram-se, em diferentes países, os mais diversos produtos confeccionados com leite de búfala, entre eles leite condensado, leite em pó integral ou desnatado, produtos lácteos indígenas, manteiga e leite fermentado. Adicionalmente, uma grande variedade de queijos vem utilizando o leite de búfala como matéria-prima.

No Brasil, o queijo tipo mussarela corresponde ao principal produto obtido a partir do leite de búfala, seguindo a tecnologia de produção tradicional italiana, caracterizada pelo uso de leite cru e pelo intenso contato entre produto 
e manipulador, o que pode comprometer a qualidade do produto final. Entretanto, poucos são os trabalhos que abordam as características microbiológicas desse queijo, na forma como ele é exposto à comercialização. Mesmo assim, o produto está no mercado, mostrando alta aceitação pelos consumidores e oferecendo excelentes perspectivas.

Nesse contexto, desenvolveu-se o presente trabalho com a finalidade de avaliar a qualidade microbiológica de duas marcas comerciais de queijo mussarela, elaborado a partir de leite de búfala, distribuídas no comércio varejista da cidade de Piracicaba/SP. 


\section{REVISÃO DE LITERATURA}

\subsection{0 búfalo}

Segundo Halbig (1994), a formação do rebanho bubalino brasileiro teve início em 1895, quando os primeiros animais foram introduzidos, oficialmente, através da llha de Marajó.

Conforme dados da FAO (2002), o Brasil possui atualmente o maior rebanho da América Latina, constituído de 1.150 .000 cabeças. De acordo com o Anuário Estatístico do Brasil (2000), as criações de búfalo estão distribuídas em todos os Estados brasileiros, localizando-se no Pará a maior concentração desse animal.

Almeida (1994), descrevendo as variadas utilizações do búfalo nos diferentes continentes, mencionou o seu uso no cultivo do solo, tracionando veículos e implementos; na dieta alimentar, fornecendo carne e leite e na confecção de vestuários, calçados, adornos e móveis, fornecendo couro, chifre e outros subprodutos. Além disso, auxilia na fertilização do solo, produzindo esterco; na limpeza de terrenos, ingerindo forragens mais grosseiras e de baixa qualidade e no transporte de materiais, entre outras utilizações (Nascimento \& Carvalho, 1993).

De acordo com Fonseca (1987), o búfalo se prolifera facilmente em áreas onde os bovinos e zebuínos não se adaptam; consome forrageiras mais rústicas não apreciadas por essas raças; apresenta grande ganho de peso e oferece grande resistência às doenças e moléstias parasitárias. 
Características como rusticidade, docilidade, resistência, longevidade, precocidade, proliferidade e grande adaptabilidade o destacam como uma considerável alternativa para a produção de proteína de alta qualidade para a população, tanto para consumo interno quanto para exportação (Fonseca, 1987).

O grande potencial, seja para a produção de carne como de leite, é enfatizado por diversos autores (Cockrill, 1981; FAO, 1991; Nascimento \& Carvalho, 1993; Nascimento et al., 1981).

Tradicionalmente, o búfalo vem sendo criado como animal para abate. Entretanto, os rebanhos leiteiros vêm aumentando e confirmando o crescente interesse pela exploração de seu potencial leiteiro (Bernardes \& Bernardes, 1993), particularmente nos Estados da região Sudeste (Macedo et al., 2001).

De acordo com Franzolin Neto (1993), assim como no rebanho bovino, a produção de leite poderá ser incrementada pela seleção de fêmeas de alta produção e pelo manejo correto em um ambiente favorável à espécie.

\subsection{O leite de búfala e seus derivados}

Segundo a FAO (1991), a maior diferença visual entre o leite de búfala e o de vaca está na sua coloração branca, sendo igualmente brancos a manteiga e os queijos produzidos com esse leite. De acordo com Fonseca (1987), no leite de búfala existe ausência de pigmentos carotenóides, estando presente a vitamina $A$, que é incolor. Já no leite de vaca encontra-se a pró-vitamina $A$ ou caroteno, responsável pela coloração amarelada da gordura.

Incontestavelmente, o leite de búfala possui teores de gordura, proteína, extrato seco total e alguns minerais que superam consideravelmente os do leite bovino, como comprovado por diversos autores (Antunes et al., 1988; Furtado, 1980a; Macedo et al., 2001; Verruma \& Salgado, 1994). A Tabela 1 compara a composição química dos leites provenientes dessas duas espécies animais. 
Tabela 1. Composição química de leites bovino e bubalino.

\begin{tabular}{ccc}
\hline Parâmetros determinados & \multicolumn{2}{c}{ Leite } \\
\cline { 2 - 3 } & Vaca & Búfala \\
\hline Umidade (\%) & 88,00 & 83,00 \\
Gordura (\%) & 3,68 & 8,16 \\
Proteína (\%) & 3,70 & 4,50 \\
Cinzas (\%) & 0,70 & 0,70 \\
Extrato seco total (\%) & 12,00 & 17,00 \\
Vitamina A (U.I.) & 185,49 & 204,27 \\
Calorias (em 100mL) & 62,83 & 104,29 \\
\hline
\end{tabular}

Fonte: Verruma \& Salgado (1994)

O consumo direto de leite de búfala integral ou após desnate parcial é observado na Índia e em outros países asiáticos (Ferrara \& Intrieri, 1975). Entretanto, o alto teor de matéria gorda nesse leite lhe confere características organolépticas indesejáveis, além de dificultar a sua assimilação pelo organismo humano. Dessa forma, desenvolveu-se na Índia um produto conhecido como "toned milk", resultante da mistura do leite de búfala com leite em pó desnatado e água (Vieira \& Neves, 1980). Assim, passou a ser distribuído para o consumo humano na forma diluída, tornando-se mais digestivo.

No Brasil, o consumo do leite de búfala em seu estado natural ainda não é difundido. Com a finalidade de criar alternativas para a utilização direta desse leite, Vieira \& Neves (1980) obtiveram uma padronização do seu teor de gordura e do extrato seco desengordurado, pela adição de leite reconstituído. Os autores observaram que o leite padronizado apresentou, no exame organoléptico, uma melhor aceitação que o leite de búfala integral.

Entretanto, a grande importância desse alimento está na sua transformação em derivados, uma vez que o seu elevado teor de extrato seco, incluindo gordura e proteína, possibilita um alto rendimento industrial (Macedo et al., 2001). De acordo com esses autores, observou-se no Brasil, na década 
de 1990, um grande aumento no número de laticínios que operam exclusivamente com o leite bubalino.

Entre os produtos elaborados a partir desse leite em diferentes países, são citados o leite condensado, leite em pó integral ou desnatado, manteiga, leite fermentado, diversos tipos de queijos e produtos lácteos indígenas, como "ghee", "khoa" e "paneer" (Ferrara \& Intrieri, 1975; Ganguli, 1979).

A utilização do leite de búfala para a elaboração de diversos queijos vem sendo bastante estudada no Brasil. Furtado (1980b) comprovou a viabilidade de fabricação do queijo azul a partir desse leite. O autor ainda concluiu que a ausência de pigmentos carotenóides no leite favorece a obtenção de uma massa branca, ideal na fabricação de queijos marmorizados, como o queijo azul, gorgonzola e similares.

Yunes \& Benedet (2000) desenvolveram um queijo fresco (Minas frescal), utilizando como matéria-prima o leite de búfala, na tentativa de introduzir esta rica fonte de proteína no hábito alimentar do brasileiro.

Como alternativa para o aproveitamento do elevado teor de gordura do leite de búfala, Fernandes \& Martins (1980) estudaram o seu emprego na fabricação de requeijão cremoso, enquanto Van Dender et al. (1988) utilizaram o creme de leite de búfala para a fabricação de queijo tipo mascarpone. Em ambos os casos, mesmo com a diferença de coloração entre os queijos obtidos com leite de búfala (branco-esverdeada) e com leite de vaca (amarelada), não foram observados problemas de aceitação destes produtos.

Van Dender (1989) citou alguns tipos de queijos que podem ser obtidos a partir do leite de búfala, como o Minas frescal, o azul, o quark, o requeijão cremoso, o mascarpone e a ricota. Ferreira et al. (1995) também destacaram o queijo tipo prato.

Ferrara \& Intrieri (1975) descreveram a técnica de elaboração de mussarela e provola a partir do leite de búfala. Ressaltaram ainda a alta potencialidade desse leite para a fabricação de diversos outros tipos de queijo. De acordo com os autores, a fabricação de queijo cheddar é difundida em 
vários países, incluindo a Índia, o Iraque e o Egito. Já na Itália, grande parte da produção desse leite é destinada à elaboração de mussarela.

\subsection{Características da mussarela de leite de búfala}

No Brasil, a mussarela também se destaca como um dos principais queijos elaborados com leite de búfala, apresentando tecnologia de fabricação semelhante à utilizada para o leite bovino.

De acordo com as Normas Técnicas Especiais Relativas a Alimentos e Bebidas (N.T.A.) (São Paulo, 1992), o queijo tipo mussarela é o produto obtido a partir de leite de vaca, de cabra, de ovelha, de búfala, ou com qualquer combinação de dois ou mais destes leites, de massa filada e não prensada, exposto ao consumo até cinco dias após a fabricação.

Embora atualmente a mussarela seja fabricada com leite de vaca, Ferrara \& Intrieri (1975) ressaltaram que a mussarela típica e original foi preparada com leite de búfala integral.

Segundo Consalvo (1997), a demanda de mussarela de leite de búfala na Itália varia de acordo com as estações. Durante o verão, enquanto a demanda aumenta, a disponibilidade desse produto diminui pela falta de matéria-prima, uma vez que o leite de búfala é produzido em grandes

quantidades durante o outono-inverno, quando a demanda é menor. Assim, a fim de preencher o déficit no período de sua maior demanda, muitas fábricas recorrem ao leite de outras espécies, prejudicando dessa forma a qualidade do produto final.

Ainda de acordo com esses autores, o sul da Itália apresenta o maior consumo médio per capita de mussarela de leite de búfala, estimado em $7,42 \mathrm{Kg} / \mathrm{ano}$, quando comparado ao consumo em outras regiões desse país (Tabela 2). 
Tabela 2. Consumo médio per capita de queijo mussarela na Itália.

\begin{tabular}{ccccc}
\hline & $\begin{array}{c}\text { Mussarela de } \\
\text { leite bovino }\end{array}$ & \multicolumn{3}{c}{$\begin{array}{c}\text { Mussarela de } \\
\text { leite bubalino }\end{array}$} \\
\cline { 2 - 5 } & Kg/ano & Índice (\%) & Kg/ano & Índice (\%) \\
\hline Noroeste & 5,42 & 84,3 & 1,72 & 47,0 \\
Nordeste & 4,46 & 69,4 & 1,58 & 43,2 \\
Centro & 7,49 & 116,5 & 3,91 & 106,8 \\
Sul e Ilhas & 8,33 & 129,5 & 7,42 & 202,7 \\
Média & 6,43 & 100,0 & 3,66 & 100,0 \\
\hline
\end{tabular}

Fonte: Consalvo (1997)

Segundo Fox \& Guinee (1987), a produção inicial de queijos de massa filada estava concentrada no sul da Itália e na Sicília, utilizando-se freqüentemente o leite da espécie bubalina como matéria-prima. Entretanto, a manufatura desses queijos não está mais restrita ao seu local de origem.

O processo de fabricação da mussarela de leite de búfala envolve a obtenção da coalhada, a sua acidificação, a fusão em água quente, o esticamento até a obtenção de uma massa macia e homogênea (filagem), o corte, a moldagem dessa massa, o endurecimento e a salga em salmoura fria (Valle, 1989). Segundo o autor, esse queijo pode se apresentar com forma e peso variados, sendo consumido puro ou fazendo parte de diversos pratos. Devido às peculiaridades da tecnologia de preparo, é produzido no Brasil principalmente por pequenas indústrias e a nível artesanal, sendo distribuído por quase todo o país.

Bonassi et al. (1982) obtiveram o queijo mussarela a partir de leite bubalino, utilizando-o isoladamente ou em combinação com leite bovino. Segundo esses autores, a elaboração de mussarela a partir de leite de búfala é justificada pelo seu alto valor nutritivo e pela disponibilidade desse leite em determinadas regiões da América Latina. Valle (1989) também ressaltou o alto rendimento proporcionado pela utilização desse leite na fabricação da mussarela. 
Além disso, a mussarela de leite de búfala caracteriza-se por ser um produto bem aceito e bem remunerado pelo consumidor, o que torna a criação de búfalos uma boa fonte de renda para o produtor (Macedo et al., 2001).

No trabalho de Verruma (1993), demonstrou-se que esse queijo apresenta características organolépticas satisfatórias para o consumo humano.

De acordo com Ferrara \& Intrieri (1975), a mussarela autêntica de búfala apresenta uma superfície branco-porcelana, crosta muito delgada (menos de $1 \mathrm{~mm})$, forma esférica, estrutura em camadas finas, superpostas, tendendo a decomporem-se na parte mais interna. O sabor é "sui generis" e a consistência é levemente elástica nas primeiras 9-12 horas de fabricação.

Verruma et al. (1993) constataram maiores níveis de proteína, gordura, extrato seco total e alguns minerais na mussarela de leite de búfala, quando comparada à produzida com leite bovino.

Ferrara \& Intrieri (1975) mencionaram que o percentual de umidade nesse tipo de queijo oscila entre 38 e 45\%, enquanto Bonassi et al. (1982) e Verruma et al. (1993) obtiveram queijos com 48,12 e 48\%, respectivamente. Para Castaldo (1960), a típica mussarela de leite de búfala da Itália possui umidade em torno de 57\%. Já a legislação brasileira estabelece um valor máximo de umidade de 58\% p/p para esse produto (São Paulo, 1992).

Quanto ao pH, Ferrara \& Intrieri (1975) mencionaram valores entre 5,5 e 5,8 para a mussarela de leite de búfala. Bonassi et al. (1982) encontraram um valor médio de 5,48, em queijos logo após a sua fabricação. Já os queijos armazenados por 7 dias a $6^{\circ} \mathrm{C}$ em salmoura, obtidos por Cortesi et al. (1997), apresentaram valores de $\mathrm{pH}$ de 5,54 e 5,63. Segundo Jay (1992), situam-se entre 4,0 e 5,0 os valores mínimos de pH necessários para o crescimento de alguns microrganismos patogênicos, tais como Staphylococcus aureus, Salmonella spp., Bacillus cereus, Yersinia enterocolitica, Vibrio parahaemolyticus e Clostridium botulinum.

Desde 1975, a mussarela de leite de búfala já era comercializada em banho de soro ou em embalagem a vácuo. Segundo Ferrara \& Intrieri (1975), o 
soro contido na embalagem parafinada com fecho hermético protege completamente o produto e absorve, com o tempo, parte do sal contido na mussarela. Já a embalagem a vácuo prolonga o tempo de conservação desse queijo.

A salmoura utilizada na salga, endurecimento e resfriamento do queijo após a moldagem, diluída ou não com um pouco de água, pode também servir como líquido de transporte na embalagem da mussarela de leite de búfala (Mucchetti et al., 1997). De acordo com esses autores, a permanência prolongada em abundante salmoura até o consumo justifica a ausência de casca nesse tipo de queijo.

\subsection{Obtenção higiênica da mussarela de leite de búfala}

Observa-se na literatura uma ampla preocupação com a qualidade higiênico-sanitária dos queijos, justificada pela diversidade de produtos existentes e pela importância que eles têm nos hábitos alimentares da população saudável e na nutrição de organismos enfraquecidos, tanto por condições naturais, como infância, gravidez e idade avançada, quanto por outros processos, como fome e doença, os quais colocam em risco, direta ou indiretamente, o sistema imunológico (Silva et al., 1997).

Entretanto, são raros os trabalhos que abordam a qualidade microbiológica da mussarela de leite de búfala, na forma como ela é exposta à comercialização, sendo mais comumente encontrados estudos sobre a avaliação microbiológica do leite de búfala.

Huhn et al. (1980) afirmaram que a qualidade e durabilidade de um produto dependem, em grande parte, da qualidade da matéria-prima usada na sua fabricação. Segundo os mesmos autores, é praticamente impossível melhorar as propriedades de um produto derivado, se o número de microrganismos inicialmente presente no leite "in natura" é elevado. 
Assim como no leite bovino, o elevado valor nutritivo do leite bubalino, associado à alta atividade de água e ao $\mathrm{pH}$ próximo da neutralidade representam características que o tornam um excelente meio para o desenvolvimento de microrganismos, conferindo-lhe elevada perecibilidade.

Cunha Neto \& Oliveira (2003) ressaltaram que o leite bubalino está sujeito às mesmas fontes de contaminação microbiana existentes para o leite bovino, principalmente na ordenha e no transporte do leite até a usina de processamento.

A sanidade do rebanho representa um fator muito importante para a qualidade do leite. Diaz (1994) citou a menor susceptibilidade dos búfalos a doenças em relação aos bovinos. Ainda concluiu que, com um bom programa nutricional e com um manejo adequado, são poucos os problemas sanitários que atingem esses animais. Essas considerações passam a ser de grande significância quando se leva em conta que o leite cru, amplamente utilizado na elaboração da mussarela de leite de búfala, pode atuar como veículo de transmissão de zoonoses, tais como tuberculose, listeriose, salmonelose, brucelose, febre aftosa, entre outras.

Uma grande atenção deve também ser dedicada à limpeza dos animais antes da ordenha, dado o seu hábito de se banhar na água e se revolver na lama para a dissipação do calor e proteção contra pragas e parasitas (Nascimento \& Carvalho, 1993). Tal comportamento dificulta a obtenção higiênica do leite, uma vez que pode contribuir para aumentar significativamente a carga microbiana inicial do leite cru, reduzindo assim a qualidade e validade do produto e limitando o seu emprego industrial (Cunha Neto \& Oliveira, 2003).

De acordo com De Franciscis \& Di Pablo (1994), algumas práticas possibilitam a obtenção de leite com baixos níveis de bactérias, tais como a eliminação do esterco dos piquetes uma ou duas vezes diariamente e a construção de uma sala de lavagem. Tais medidas, segundo os autores, refletem em maior conservabilidade para os derivados, como a mussarela. 
Vieira et al. (1994) realizaram a avaliação microbiológica de leite de búfala sob diferentes práticas higiênicas na ordenha. Os resultados permitiram concluir que o melhor método para higienização foi banho seguido de lavagem do úbere com solução bactericida.

Vianni et al. (2000), avaliando a qualidade microbiológica de leite "in natura" proveniente de rebanhos bubalinos do Estado do Rio de Janeiro, encontraram valores médios de 7,6 x 104 UFC/mL, 8,0 x $10^{4} \mathrm{UFC} / \mathrm{mL}$ e 2,2 $\mathrm{x}$ $10^{5} \mathrm{UFC} / \mathrm{mL}$ para bactérias mesófilas aeróbias em amostras provenientes de quartos mamários individuais, do leite de cada búfala ordenhada (leite individual) e do leite de todos os animais (leite de mistura), respectivamente. Tais resultados permitiram concluir que a qualidade do leite "in natura" dos rebanhos estudados estava muito inferior ao esperado, devido ao elevado número de bactérias deterioradoras, comprometendo o período de vida útil do leite e evidenciando a falta de adoção de medidas higiênico-sanitárias antes, durante ou após a ordenha. Ainda, ao compararem o leite individual com o leite de mistura, os autores comprovaram que a carga microbiana se elevou com o aumento da manipulação do leite, uma vez que a contaminação média do leite de mistura foi superior a do leite individual.

Levando-se em conta que o número de contaminantes do leite vai aumentando gradativamente, a partir do momento da sua obtenção, ressalta-se a importância da conservação adequada do leite recém-ordenhado como prática fundamental para a manutenção da sua qualidade. Dessa forma, o leite deve ser submetido a baixas temperaturas imediatamente após a ordenha, evitando-se assim a proliferação de microrganismos indesejados.

O Regulamento de Inspeção Industrial e Sanitária de Produtos de Origem Animal (RIISPOA) discorre, detalhadamente, sobre procedimentos que devem ser seguidos durante o manejo do leite, desde a sua obtenção até a sua utilização pela indústria processadora (Brasil, 1980). Em linhas gerais, o regulamento estabelece que a temperatura de resfriamento do leite deve assegurar a inibição temporária do desenvolvimento microbiano, além de variar 
de acordo com o manejo adotado, porém essa temperatura não ultrapassa $10^{\circ} \mathrm{C}$.

Embora não possa evitar o desenvolvimento de microrganismos psicrotróficos, o resfriamento do leite mostra-se adequado quando se leva em conta a alta incidência de bactérias do gênero Staphylococcus como causadoras da mastite bubalina. Paranjape \& Das (1986), estudando os agentes causadores de mastite em fêmeas bubalinas na Índia, observaram que o microrganismo predominante foi Staphylococcus spp, seguido por Streptococcus spp.

Analisando a etiologia da mastite em rebanhos bubalinos da Venezuela, Brinez et al. (2000) observaram que as principais espécies bacterianas envolvidas pertenciam aos gêneros Staphylococcus e Micrococcus.

No Brasil, um estudo realizado em 10 rebanhos bubalinos leiteiros do Estado de São Paulo revelou que o gênero de maior prevalência foi Staphylococcus, seguido por Corynebacterium e Streptococcus (Costa et al., 1997).

Com a refrigeração, evita-se a proliferação de bactérias do gênero Staphylococcus em leite contaminado, proveniente de búfalas doentes, prevenindo-se a produção de enterotoxinas por determinadas cepas desse gênero. Sabe-se que, uma vez produzidas no leite cru, as enterotoxinas estafilocócicas não são destruídas pelos tratamentos térmicos comumente empregados ao leite, permanecendo assim nos produtos derivados e acarretando intoxicação pelo consumo dos mesmos.

A incidência de bactérias formadoras de esporos em leite cru tem sido observada por alguns autores. Shehata et al. (1983) relataram que a presença de bactérias mesófilas aeróbias formadoras de esporos no leite de búfalas variou com as estações do ano, onde as contagens alcançaram valores de 1,0 $\mathrm{x}$ $10^{2}$ a $8,1 \times 10^{4} \mathrm{UFC} / \mathrm{mL}$, sendo que o verão apresentou a maior contagem média $\left(1,6 \times 10^{4} \mathrm{UFC} / \mathrm{mL}\right)$, diferenciando-se portanto do inverno, com a menor contagem média $\left(5,7 \times 10^{3} \mathrm{UFC} / \mathrm{mL}\right)$. As espécies isoladas variaram durante 0 
ano e consistiram principalmente de Bacillus subtilis (42,5\%) e Bacillus megaterium (34,8\%), seguidos por Bacillus circulans (4,9\%), Bacillus cereus (4,6\%), Bacillus pumilus (2,9\%), Bacillus polymyxa (2,8\%), Bacillus licheniformis (1,9\%), Bacillus badius (1,5\%), Bacillus brevis (1,3\%), Bacillus pulvifaciens $(1,2 \%)$, Bacillus coagulans (1,1\%) e Bacillus firmus (0,5\%). Cinco dessas espécies mostraram-se como psicrotróficas, como é o caso de Bacillus cereus (42,6\%), Bacillus pumilus (31,9\%), Bacillus badius (13,8\%), Bacillus licheniformis (10,6\%), Bacillus firmus $(2,1 \%)$, sendo que todas as cepas psicrotróficas pertencentes a Bacillus cereus, Bacillus badius e Bacillus firmus foram capazes de deteriorar leite desnatado refrigerado a $7^{\circ} \mathrm{C}$.

Portanto, o isolamento de espécies de Bacillus no leite cru representa um problema para o leite pasteurizado e produtos derivados elaborados com leite tratado termicamente, uma vez que os esporos dessas bactérias apresentam grande resistência térmica e podem sobreviver a tratamentos térmicos comumente empregados ao leite (pasteurização e esterilização). Como demonstrado por esses autores, tais esporos podem ainda germinar, crescer e deteriorar produtos armazenados sob refrigeração, o que pode representar uma grande ameaça à qualidade da mussarela de leite de búfala.

Para Cunha Neto \& Oliveira (2003), a obtenção do leite de búfala deve seguir os mesmos critérios de qualidade empregados na bovinocultura leiteira. Para isso, práticas relacionadas com a melhoria da qualidade do leite "in natura" devem ser asseguradas, tais como, a manutenção dos estábulos de ordenha em boas condições higiênicas, a limpeza e sanitização eficientes dos utensílios e equipamentos, a aquisição de sistemas adequados à obtenção (ordenhadeiras) e à conservação do leite (resfriadores), a adoção de Boas Práticas de Manipulação nos trabalhos de ordenha, o manejo sanitário adequado do rebanho, o controle de mastites e a provisão de água de boa qualidade.

A pasteurização do leite também se destaca como uma prática que ajuda na obtenção de derivados de boa qualidade. Empregada com a finalidade de 
destruir todos os microrganismos causadores de doenças (Landgraf, 2000), a pasteurização acaba se prestando também à redução da carga microbiana inicial, diminuindo a ocorrência de microrganismos deteriorantes e aumentando a vida útil do produto (Varnam \& Sutherland, 1994). Portanto, a destruição de microrganismos patogênicos não esporulados como Salmonella spp., Listeria spp., Yersinia enterocolitica, Campylobacter jejuni, Vibrio spp., Escherichia coli O157:H7, Shigella spp. e Staphylococcus coagulase-positiva, deve ser assegurada pela pasteurização, uma vez que tais microrganismos apresentam baixa resistência térmica.

Segundo os mesmos autores, a pasteurização do leite pode ser atingida pela aplicação de diferentes combinações de tempo / temperatura. Normalmente, o leite é submetido a $62,8^{\circ} \mathrm{C}$ por 30 minutos, denominada baixa temperatura / tempo longo (low temperature / long time: LTLT), ou a $71,7^{\circ} \mathrm{C}$ por 15 segundos, denominada alta temperatura / tempo curto (high temperature / short time: HTST).

Embora a pasteurização seja uma etapa essencial na elaboração de queijos, a mussarela de leite de búfala vem sendo produzida a partir de leite cru. Silva et al. (1999) citaram que, para alguns autores italianos, a pasteurização do leite acarreta prejuízos de ordem tecnológica, bem como perda das características organolépticas do produto final.

Pelo fato de ser um queijo de massa filada, a necessidade da prática de pasteurização do leite, durante a elaboração da mussarela, vem sendo questionada. Segundo Valle (1989), a filagem consiste em uma das etapas de fabricação desse queijo, quase sempre realizada manualmente, na qual a massa é colocada na água quente $\left(85-90^{\circ} \mathrm{C}\right)$, na proporção de até 1:3 (massa:água quente), com a finalidade de lhe conferir uma estrutura contínua e filamentosa. Variações para a temperatura da água de filagem podem ser encontradas, como no processo de fabricação descrito por Mucchetti et al. (1997), no qual a água quente adicionada encontrava-se a uma temperatura de 
$95^{\circ} \mathrm{C}$. De acordo com esses autores, o processo de filagem pode durar de 3,5 a 6 minutos.

Silva et al. (1999) demonstraram que a fase de filagem, durante a elaboração de mussarela com leite cru de búfala, apresentou potencial microbiocida e atuou sobre as enzimas fosfatase alcalina e peroxidase, sugerindo uma eficiência comparável à da pasteurização do leite. As temperaturas das águas utilizadas no processo de filagem foram bastante superiores às temperaturas de pasteurização normalmente empregadas para 0 leite, variando de 81 a $98^{\circ} \mathrm{C}$, sendo que a temperatura se mostrou igual ou superior a $90^{\circ} \mathrm{C}$ em $65,63 \%$ das aferições. Os autores ressaltaram, porém, a necessidade de se estabelecer a temperatura mínima da água a ser utilizada para a filagem.

Mucchetti et al. (1997) também afirmaram que o baixo valor de $\mathrm{pH}$ conferido pela fermentação lática, sempre abaixo de 4,95, aliado à combinação de tempo / temperatura durante a filagem $\left(68,3^{\circ} \mathrm{C}\right.$ por 3 minutos), permitem considerar o efeito desta fase comparável ao obtido pela pasteurização.

Entretanto, os riscos à saúde pública associados à falta de pasteurização do leite devem ser ponderados, mesmo considerando que a filagem do queijo seja realizada em água quente (Valle, 1989). O alto conteúdo de gordura da massa fermentada, assim como a distribuição desuniforme do calor através da massa durante a filagem podem prejudicar a eficiência dessa fase, no que se refere à destruição de microrganismos. Além disso, Busani (1989) ressaltou que a pasteurização é considerada indispensável, do ponto de vista técnico, para se manter o mesmo padrão de qualidade para todos os derivados do leite de búfala.

De acordo com Valle (1989), na elaboração da mussarela, a massa fermentada obtida com leite cru apresenta inúmeros orifícios irregulares, produzidos principalmente por coliformes, enquanto a massa obtida a partir de leite pasteurizado é compacta, fechada e praticamente sem orifícios internos, revelando assim uma fermentação normal. Além disso, o uso de leite cru na 
fabricação de queijos pode levar ao aparecimento de defeitos, como o estufamento precoce, em que os queijos se apresentam ligeiramente abaulados, devido à formação de gás na massa, e com características sensoriais alteradas, como sabor picante ou levemente amargo e desagradável.

Silva et al. (1997) afirmaram que a eficiência da filagem é tanto maior quanto menor o nível microbiano inicial do leite. Dessa forma, consideraram que a pasteurização pode ter um efeito adicional sobre o processo de filagem, conferindo uma redução da contaminação a níveis aceitáveis e melhorando as condições da matéria-prima, e deve ser adotada em combinação ao uso de "starters" adequadamente desenvolvidos para garantir ao produto suas características típicas. Entretanto, alertaram sobre os riscos representados pelas enterotoxinas estafilocócicas, uma vez que não são destruídas pela pasteurização e filagem, vindo daí a importância da refrigeração do leite logo após a ordenha.

Associado ao controle de qualidade do leite deve estar o cuidado com outros ingredientes utilizados na elaboração da mussarela de leite de búfala. Coppola et al. (1988) observaram a ocorrência de patógenos potenciais no soro-fermento, utilizado como "starter" na tecnologia tradicional de manufatura desse tipo de queijo.

O estreito contato entre produto e manipulador, durante a fabricação da mussarela de leite de búfala, pode também influenciar na qualidade do produto final. Silva et al. (1999) verificaram a contaminação da mussarela por Staphylococcus coagulase-positiva apenas após a filagem, indicando provável contaminação pelo manipulador. Os autores atentaram para a necessidade de um rigoroso controle higiênico-sanitário do ambiente da fábrica, operadores e utensílios, uma vez que o processo de manufatura da mussarela de leite de búfala ainda exige muita manipulação, o que predispõe o produto final a contaminantes não oriundos do leite e que, eventualmente, possam afetar a saúde do consumidor. 
Apesar da técnica utilizada atualmente na manufatura da mussarela de leite de búfala ainda se basear no procedimento tradicional italiano, caracterizado pela intensa manipulação, Mucchetti et al. (1997) ressaltaram que os processos artesanais vêm sendo aperfeiçoados nos últimos anos. Os autores descreveram os principais passos da tecnologia de produção tradicional, como também reportaram as recentes inovações introduzidas em algumas fábricas, entre elas a mecanização gradual das operações. Entretanto, ao comentarem sobre a simulação mecânica do processo de filagem, afirmaram que nenhum método permite chegar a produtos similares aos obtidos pela filagem manual.

Silva et al. (1997) avaliaram a influência do processo de manufatura da mussarela de leite de búfala, a partir de leite cru, sobre a qualidade microbiológica desse queijo, analisando uma linha de produção manual e outra parcialmente mecanizada. De acordo com os números de coliformes totais e fecais encontrados na massa logo após a filagem e no produto final previamente à sua embalagem, conclui-se que o sistema parcialmente mecanizado oferece mais segurança que o processo manual, no que se refere à recontaminação após filagem. Ainda concluíram que a mecanização do processo interfere positivamente para a melhoria na qualidade higiênicosanitária do queijo, desde que adotados rigorosos procedimentos de limpeza dos equipamentos.

Lück (1981) ressaltou também a importância do controle da condição microbiológica do ar, mesmo nas menores indústrias, através da ventilação mecânica e da filtração do ar, como uma prática para se evitar a contaminação durante a fabricação de derivados.

Após a obtenção higiênica da mussarela de leite de búfala, esse produto deve ser mantido sob refrigeração, por se tratar de um alimento perecível. De acordo com a literatura, a faixa de temperatura recomendada para o armazenamento refrigerado de produtos lácteos encontra-se entre 4 e $8^{\circ} \mathrm{C}$, sendo $10^{\circ} \mathrm{C}$ a temperatura máxima admissível para a estocagem de todos os 
alimentos perecíveis (Hobbs \& Roberts, 1993). Dessa forma, durante as fases de distribuição e comercialização desse queijo, oscilações de temperatura devem ser evitadas, levando-se em conta que muitos estabelecimentos comerciais, com o intuito de economizar energia elétrica, acabam oferecendo condições inadequadas de armazenamento para produtos perecíveis, comprometendo assim a qualidade dos mesmos.

Embora seja uma técnica eficiente para a manutenção da qualidade de produtos perecíveis, ressalta-se que o armazenamento refrigerado dos alimentos não evita o desenvolvimento de alguns microrganismos psicrotróficos, tanto deteriorantes como patogênicos, tais como Pseudomonas spp., Bacillus spp., Listeria spp. e Yersinia enterocolitica. No entanto, práticas como controle do $\mathrm{pH}$, da atividade de água, adição de conservantes, entre outras, podem afetar a capacidade de multiplicação de tais microrganismos, se presentes em produtos refrigerados.

\subsection{Padrões microbiológicos para a mussarela de leite de búfala}

De acordo com Landgraf (2000), é praticamente impossível que os microrganismos não tenham acesso aos alimentos.

De acordo com a International Commission on Microbiological Specifications for Foods (ICMSF) (1984), a presença de microrganismos não significa, necessariamente, produtos perigosos ou de qualidade inferior. Com exceção dos alimentos esterilizados, os demais alimentos contêm, normalmente, um certo nível de microrganismos, incluindo bolores, leveduras e bactérias.

Sendo assim, a Agência Nacional de Vigilância Sanitária (ANVISA), através da Resolução RDC n- 12 de 02 de Janeiro de 2001, estabeleceu padrões microbiológicos para diversos alimentos. Os limites de tolerância adotados para o queijo tipo mussarela estão descritos na Tabela 3. 
Tabela 3. Padrão microbiológico para queijo tipo mussarela. Microrganismo ou grupo de microrganismos Limite de tolerância

Coliformes a $45^{\circ} \mathrm{C}$

Staphylococcus coagulase-positiva

Salmonella spp.

Listeria monocytogenes
$5 \times 10^{3} \mathrm{NMP} / \mathrm{g}$ $10^{3} \mathrm{UFC} / \mathrm{g}$ Ausência em $25 \mathrm{~g}$ Ausência em $25 g$ 


\section{MATERIAL E MÉTODOS}

\subsection{Material}

Foram analisadas 2 marcas comerciais de queijo mussarela, elaborado com leite de búfala pasteurizado, sendo uma das marcas comercializada com soro (A) e a outra comercializada sem soro, em embalagem a vácuo (B), apresentando prazos de validade de 1 e 2 meses, respectivamente. Ambas as marcas apresentavam registro no Serviço de Inspeção Federal (S.I.F.).

\subsection{Métodos}

\subsubsection{Amostragem}

Foram efetuadas 12 coletas para cada marca, realizando-se 3 repetições analíticas em cada coleta, totalizando 36 amostras de cada marca.

A amostragem foi realizada durante um período de 6 meses, com coletas quinzenais das amostras, as quais pertenciam a lotes de produção diferentes e foram adquiridas dentro de 5 a 7 dias após a sua fabricação, em suas embalagens originais, em estabelecimentos comerciais da cidade de Piracicaba/SP, onde eram mantidas sob refrigeração em câmaras frigoríficas. A temperatura dessas câmaras foi medida no momento de cada coleta.

Após a aquisição, as amostras foram acondicionadas em recipiente isotérmico contendo gelo picado, sendo imediatamente encaminhadas ao laboratório de Microbiologia de Alimentos do Departamento de Agroindústria, 
Alimentos e Nutrição da ESALQ/USP, onde foram submetidas às análises microbiológicas.

\subsubsection{Preparo das amostras}

Os procedimentos utilizados no preparo das amostras seguiram as recomendações descritas no Compendium of Methods for the Microbiological Examination of Foods (Vanderzant \& Splittstoesser, 1992).

As embalagens foram desinfetadas externamente com álcool e abertas com tesoura estéril. O soro contido nas embalagens da marca $A$ foi eliminado. Todo o conteúdo da embalagem foi picado com faca estéril em fatias bem finas e, a partir desse material, foram compostas as 3 repetições analíticas, como também retirada uma porção para a determinação de pH .

Para a contagem de Staphylococcus coagulase-positiva e determinação do NMP de coliformes totais e fecais, foram preparadas diluições em série (Figura 1). Para isso, $20 \mathrm{~g}$ de cada amostra foram triturados em liquidificador, em copo metálico previamente esterilizado, com $180 \mathrm{~mL}$ de Água Peptonada Esterilizada $0,1 \%$, obtendo-se assim a diluição $10^{-1}$. A partir dessa diluição, foram feitas diluições em série até $10^{-3}$, sempre transferindo $10 \mathrm{~mL}$ de cada diluição para $90 \mathrm{~mL}$ de Água Peptonada Esterilizada 0,1\%. 


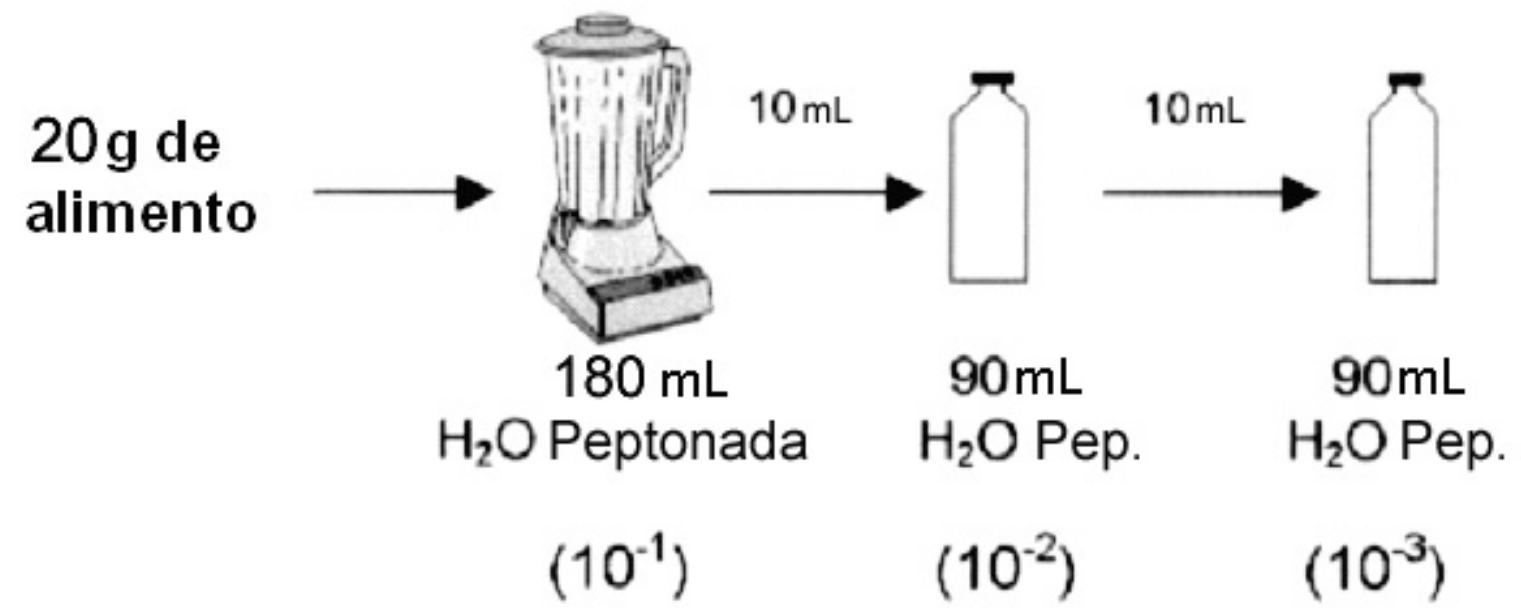

Figura 1 - Preparo de diluições em série.

As determinações de Salmonella spp. e de Listeria spp. dispensaram o uso de diluições, uma vez que estes microrganismos devem estar ausentes em $25 \mathrm{~g}$ de qualquer produto alimentício. Para estas análises fez-se um préenriquecimento com meios de cultivo específicos para cada um desses microrganismos.

As análises microbiológicas realizadas em cada repetição estão descritas a seguir.

\subsubsection{Análises microbiológicas}

\subsubsection{Determinação do NMP de coliformes totais e fecais}

Para a determinação do NMP de coliformes totais e fecais foi utilizada a técnica dos tubos múltiplos, conforme metodologia descrita pela Associação Brasileira de Normas Técnicas (ABNT) (1991).

Essa técnica compreende duas fases distintas: o teste presuntivo, no qual se recuperam células injuriadas e se detecta a presença de 
microrganismos fermentadores da lactose, e o teste confirmativo, onde se determina a população real de coliformes totais e fecais.

De acordo com essa norma, a prova presuntiva não é efetuada no exame de produtos lácteos, sendo as inoculações realizadas diretamente em Caldo Verde Brilhante Lactose Bile (CVBLB) 2\%, utilizado para a confirmação de coliformes totais.

Os sais biliares e o verde brilhante presentes nesse meio de cultura inibem o crescimento de microrganismos Gram positivos e oferecem condições para o desenvolvimento de microrganismos adaptados às condições gastrintestinais, favorecendo dessa forma o crescimento do grupo coliforme. $\mathrm{Na}$ presença de microrganismos desse grupo, a lactose presente no meio é fermentada, resultando na produção de gás.

No teste confirmativo para coliformes totais foram utilizadas 3 séries de 3 tubos contendo CVBLB 2\% e tubos de Duhram (Figura 2). A primeira série de tubos continha meio em dupla concentração e recebeu $10 \mathrm{~mL}$ de inóculo da diluição $10^{-1}$. A segunda e terceira séries continham meio em concentração normal e receberam $1 \mathrm{~mL}$ das diluições $10^{-1}$ e $10^{-2}$, respectivamente. Os tubos foram incubados a $32^{\circ} \mathrm{C}$ por $24-48$ horas. Após a incubação, a presença de bactérias do grupo dos coliformes, de origem fecal ou não, foi confirmada pelo crescimento com produção de gás, evidenciada pela formação de bolhas no tubo de Duhram. 


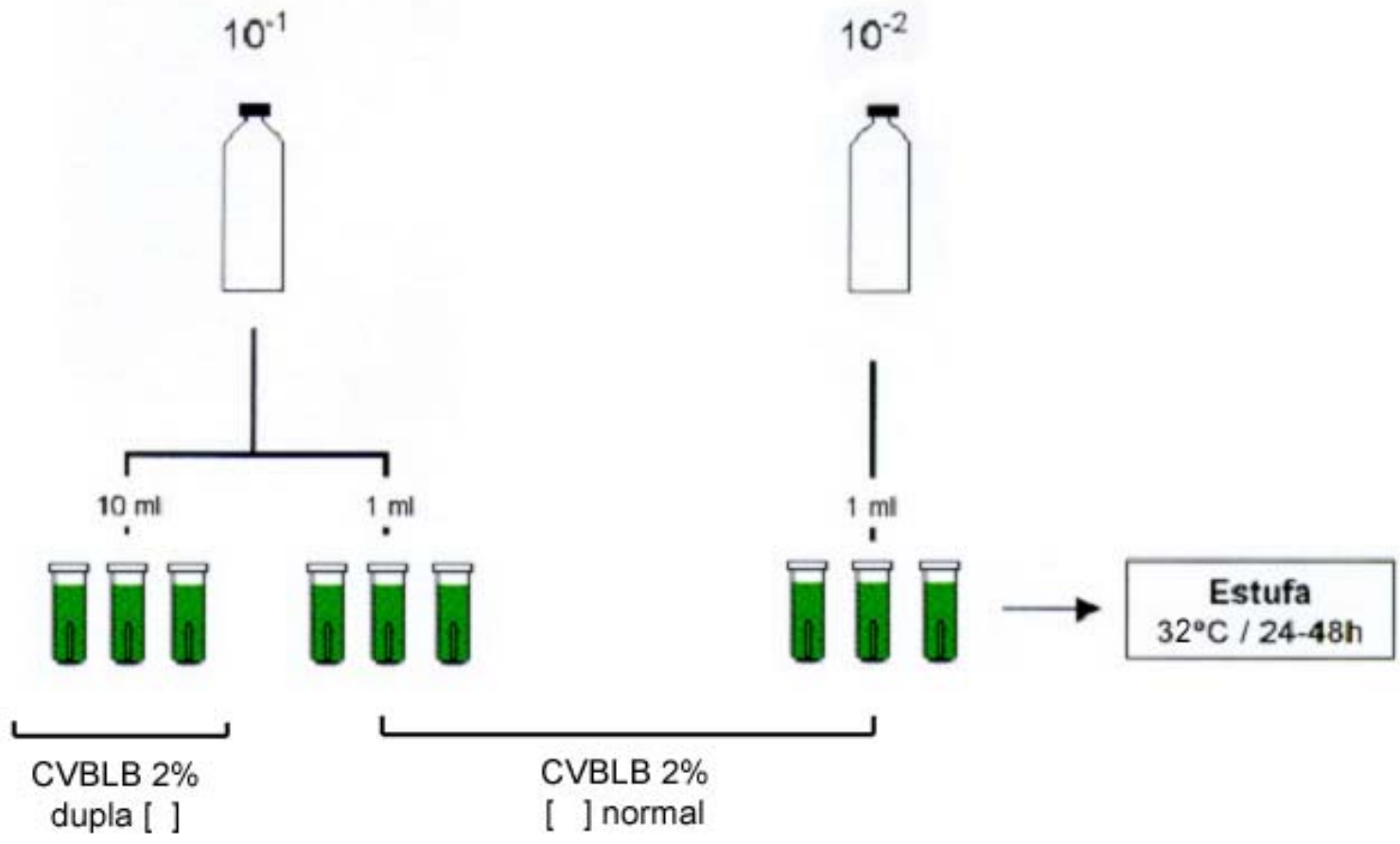

Figura 2 - Esquema do teste confirmativo para coliformes totais.

A partir dos tubos positivos, foram semeados com alça de níquel-cromo tubos do mesmo meio e tubos contendo Caldo Triptona, os quais foram incubados em banho-maria a $(44 \pm 0,1)^{\circ} \mathrm{C}$ (Figura 3). Após 24 horas de incubação, os tubos com Caldo Triptona foram submetidos à prova de produção de indol, adicionando-se em cada tubo 0,2-0,3 mL do reativo de Kovac's. A presença de indol foi detectada pela formação de um anel vermelho-escuro na superfície do meio. 


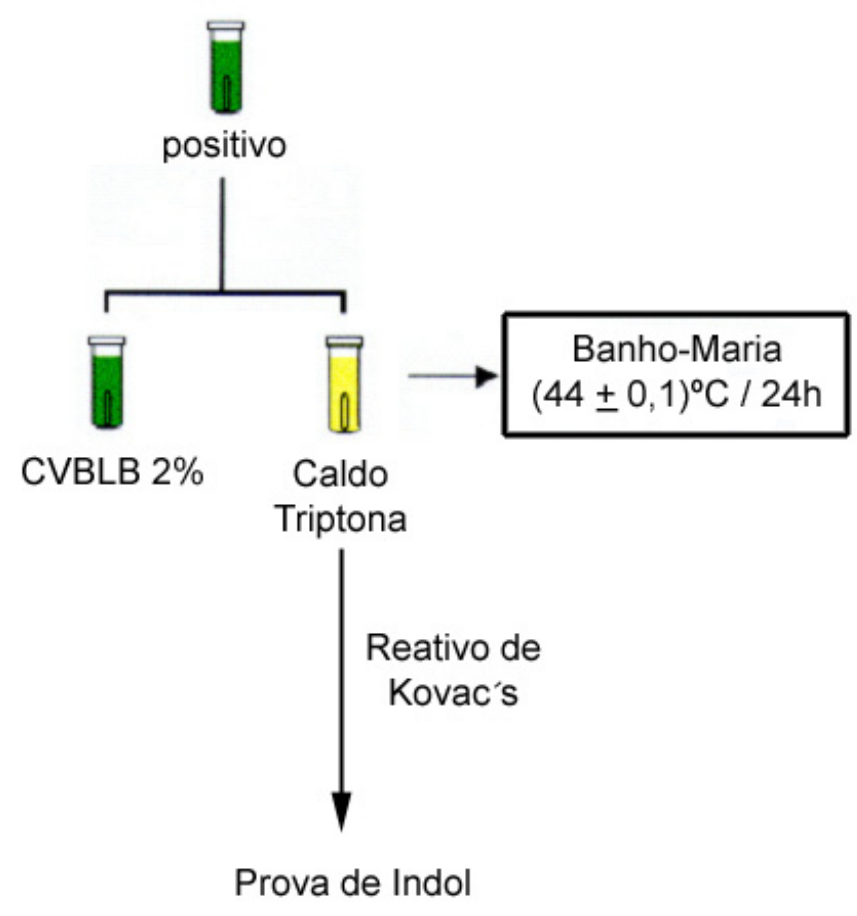

Figura 3 - Esquema do teste confirmativo para coliformes fecais.

A presença de coliformes fecais foi confirmada pela produção de indol no Caldo Triptona, além da produção de gás nos tubos com CVBLB 2\% após 24 horas de incubação a $(44 \pm 0,1)^{\circ} \mathrm{C}$, uma vez que a temperatura e o período de incubação utilizados impedem que outros microrganismos fermentem a lactose com produção de gás.

Com o auxílio de tabela própria da ABNT (1991) (Tabela 4), determinouse o NMP de coliformes totais e fecais / grama de amostra. 
Tabela 4. Número mais provável para várias combinações de resultados positivos, quando três tubos são usados por diluição (inoculações de 1,0; 0,1 e 0,01 g ou $\mathrm{mL}$ da amostra).

\begin{tabular}{|c|c|c|c|c|c|c|c|}
\hline \multirow{2}{*}{\multicolumn{3}{|c|}{$\begin{array}{l}\text { Combinação de tubos } \\
\text { positivos } \\
\text { Inoculações (g ou mL) }\end{array}$}} & \multirow{2}{*}{\multicolumn{5}{|c|}{$\begin{array}{l}\text { Combinação de tubos } \\
\text { positivos } \\
\text { Inoculações (g ou mL) }\end{array}$}} \\
\hline & & & & & & & \\
\hline 1,0 & 0,1 & 0,01 & NMP & 1,0 & 0,1 & 0,01 & NMP \\
\hline 0 & 0 & 0 & $<0,30$ & 2 & 0 & 0 & 0,91 \\
\hline 0 & 0 & 1 & 0,30 & 2 & 0 & 1 & 1,40 \\
\hline 0 & 0 & 2 & 0,60 & 2 & 0 & 2 & 2,00 \\
\hline 0 & 0 & 3 & 0,90 & 2 & 0 & 3 & 2,60 \\
\hline 0 & 1 & 0 & 0,30 & 2 & 1 & 0 & 1,50 \\
\hline 0 & 1 & 1 & 0,61 & 2 & 1 & 1 & 2,00 \\
\hline 0 & 1 & 2 & 0,92 & 2 & 1 & 2 & 2,70 \\
\hline 0 & 1 & 3 & 1,20 & 2 & 1 & 3 & 3,40 \\
\hline 0 & 2 & 0 & 0,62 & 2 & 2 & 0 & 2,10 \\
\hline 0 & 2 & 1 & 0,93 & 2 & 2 & 1 & 2,80 \\
\hline 0 & 2 & 2 & 1,20 & 2 & 2 & 2 & 3,50 \\
\hline 0 & 2 & 3 & 1,60 & 2 & 2 & 3 & 4,20 \\
\hline 0 & 3 & 0 & 0,94 & 2 & 3 & 0 & 2,90 \\
\hline 0 & 3 & 1 & 1,30 & 2 & 3 & 1 & 3,60 \\
\hline 0 & 3 & 2 & 1,60 & 2 & 3 & 2 & 4,40 \\
\hline 0 & 3 & 3 & 1,90 & 2 & 3 & 3 & 5,30 \\
\hline 1 & 0 & 0 & 0,36 & 3 & 0 & 0 & 2,30 \\
\hline 1 & 0 & 1 & 0,72 & 3 & 0 & 1 & 3,90 \\
\hline 1 & 0 & 2 & 1,10 & 3 & 0 & 2 & 6,40 \\
\hline 1 & 0 & 3 & 1,50 & 3 & 0 & 3 & 9,50 \\
\hline 1 & 1 & 0 & 0,73 & 3 & 1 & 0 & 4,30 \\
\hline 1 & 1 & 1 & 1,10 & 3 & 1 & 1 & 7,50 \\
\hline 1 & 1 & 2 & 1,50 & 3 & 1 & 2 & $1,20 \times 10$ \\
\hline 1 & 1 & 3 & 1,90 & 3 & 1 & 3 & $1,60 \times 10$ \\
\hline 1 & 2 & 0 & 1,10 & 3 & 2 & 0 & 9,30 \\
\hline 1 & 2 & 1 & 1,50 & 3 & 2 & 1 & $1,50 \times 10$ \\
\hline 1 & 2 & 2 & 2,00 & 3 & 2 & 2 & $2,10 \times 10$ \\
\hline 1 & 2 & 3 & 2,40 & 3 & 2 & 3 & $2,90 \times 10$ \\
\hline 1 & 3 & 0 & 1,60 & 3 & 3 & 0 & $2,40 \times 10$ \\
\hline 1 & 3 & 1 & 2,00 & 3 & 3 & 1 & $4,60 \times 10$ \\
\hline 1 & 3 & 2 & 2,40 & 3 & 3 & 2 & $1,10 \times 10^{2}$ \\
\hline 1 & 3 & 3 & 2,90 & 3 & 3 & 3 & $>1,10 \times 10^{2}$ \\
\hline
\end{tabular}

Fonte: ABNT (1991) 


\subsubsection{Salmonella spp.}

Para o pré-enriquecimento das amostras, triturou-se em liquidificador, em copo metálico previamente esterilizado, $25 \mathrm{~g}$ de amostra em $225 \mathrm{~mL}$ de Caldo Lactosado. Esse material foi transferido para um erlenmeyer e incubado a 35$37^{\circ} \mathrm{C}$ por 24 horas.

Para a detecção presuntiva de Salmonella spp. foi utilizado o kit rápido 12 Test, da BioControl (Figura 4). Trata-se de um método oficial aprovado pela Association of Official Analytical Chemists (AOAC) (989.13), qualitativo para a detecção das espécies móveis de Salmonella.

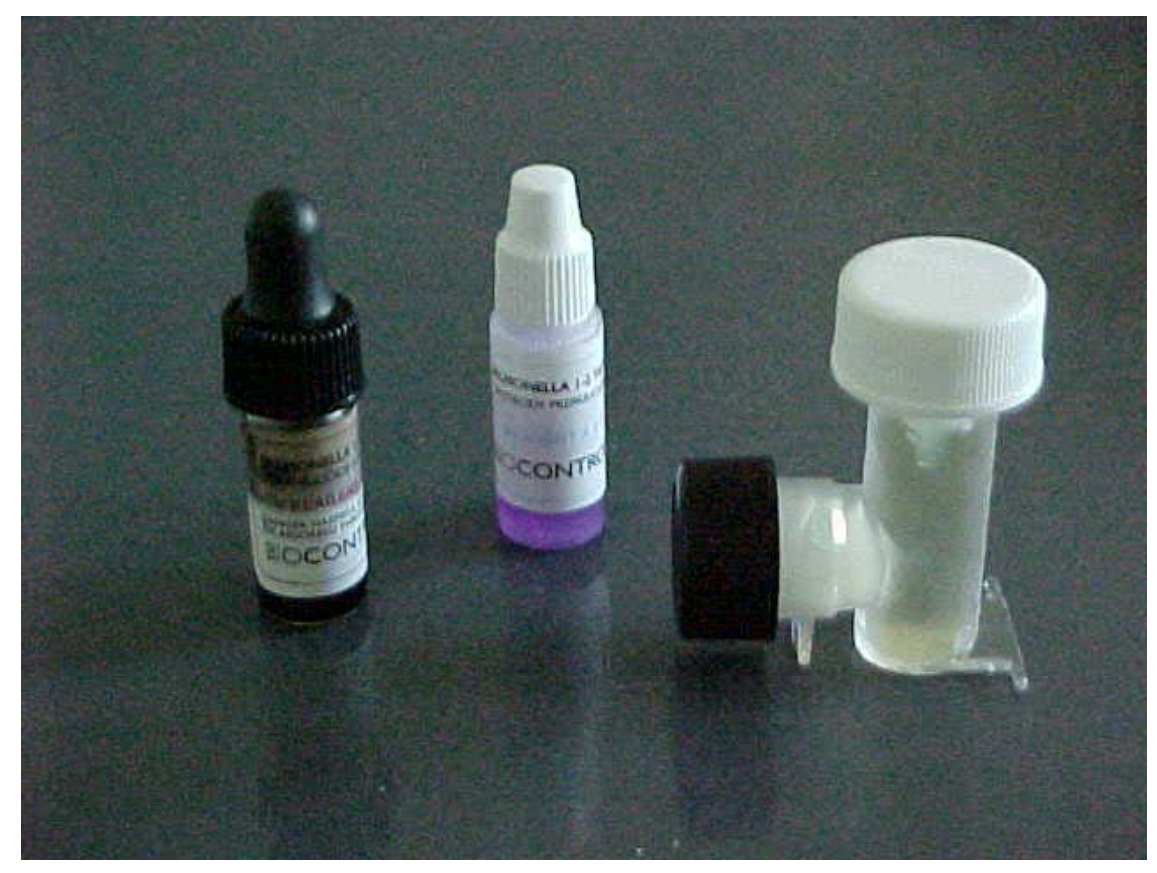

Figura 4 - Kit rápido 1,2 Test para Salmonella spp., da BioControl.

O princípio se baseia na observação da imobilização da Salmonella pelos anticorpos polivalentes $\mathrm{H}$ (flagelar) contidos no meio de motilidade, com 0 desenvolvimento de uma banda visual bem definida (imunobanda). 
A unidade de teste é composta por dois compartimentos: a câmara de inoculação, contendo Caldo Tetrationato-Verde Brilhante, e a câmara de motilidade, contendo um meio de motilidade não seletivo à base de peptona. A comunicação entre os compartimentos é vedada por um tampão, que deve ser removido antes da adição da amostra. Durante a incubação do kit inoculado, a Salmonella contida no Caldo Tetrationato-Verde Brilhante se move da câmara de inoculação para o meio de motilidade para reagir com os anticorpos, formando a imunobanda.

Uma alíquota de 0,1 mL da amostra pré-enriquecida em Caldo Lactosado foi inoculada na câmara de inoculação. O "tip" presente na tampa da câmara de motilidade, o qual forma um vão no gel, foi retirado para a adição da solução de anticorpos. Após a incubação por $14-30$ horas a $35^{\circ} \mathrm{C}$, observou-se a formação ou não da imunobanda.

\subsubsection{Listeria spp.}

Para a detecção de Listeria spp., utilizou-se o kit rápido VIP (Visual Immunoprecipitate Assay) para Listeria, da BioControl (Figura 5), como método oficial aprovado pela AOAC (997.03). 


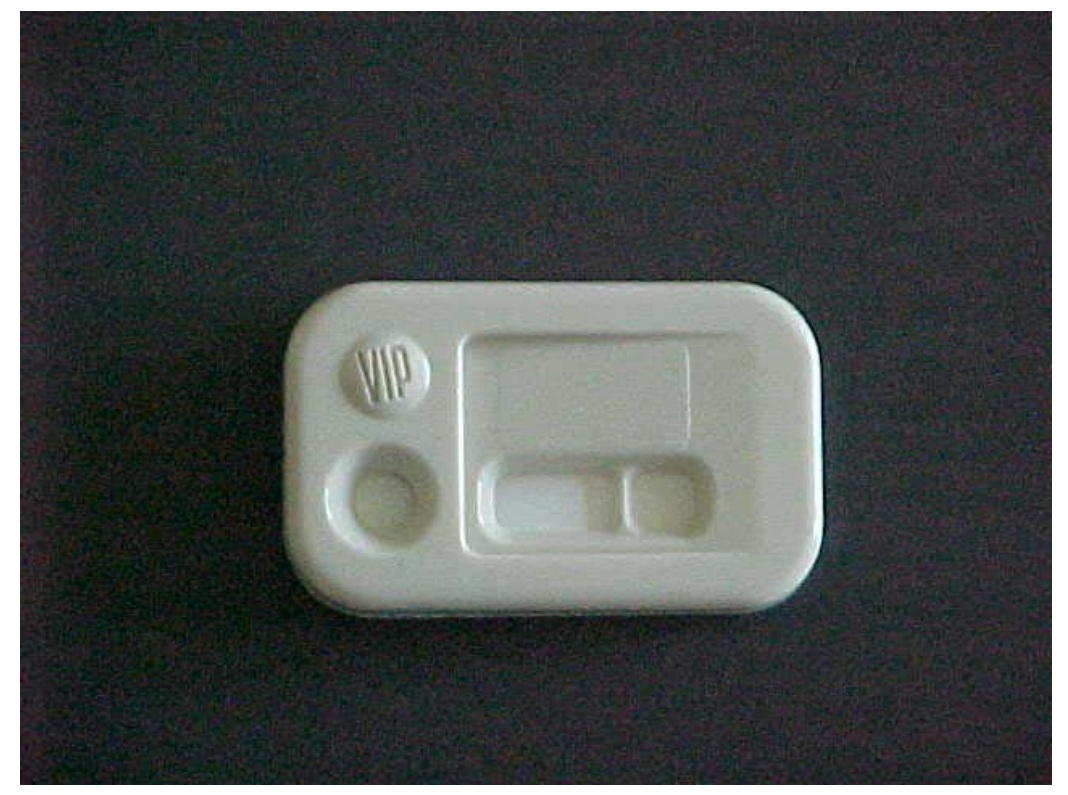

Figura 5 - Kit rápido VIP para Listeria spp., da BioControl.

O kit consiste num dispositivo plástico que apresenta uma fita de papel filtro em seu interior e 3 áreas (janelas) definidas: a área com formato circular, que corresponde à cavidade onde o meio de cultura de enriquecimento da amostra é adicionado, a área retangular maior, que consiste na janela de leitura do resultado, e a área do quadrado menor, que é a janela de verificação de funcionamento do teste, ou seja, de controle da qualidade do kit.

Após a adição do caldo de enriquecimento na primeira janela, o material migra para a segunda janela, onde ocorre o aparecimento de uma linha cinza na presença de Listeria spp., evidenciando a reação entre antígenos e anticorpos com alta especificidade para esse microrganismo, presentes no papel filtro. Além disso, uma linha cinza escuro deve aparecer sempre na terceira janela, indicando que o material migrou até essa área, atestando dessa forma o bom funcionamento do kit.

Para o enriquecimento seletivo das amostras, triturou-se em liquidificador, em copo metálico previamente esterilizado, $25 \mathrm{~g}$ de amostra com $225 \mathrm{~mL}$ de Caldo Fraser modificado com 2,65 mL de Cloreto de Lítio (LiCl) 8M. Esse material foi incubado em erlenmeyer a $30^{\circ} \mathrm{C}$ por 28 horas. Após a 
incubação, uma alíquota de $1 \mathrm{~mL}$ foi transferida para $9 \mathrm{~mL}$ de Caldo Tamponado de Enriquecimento para Listeria (BLEB), incubando-se novamente a $30^{\circ} \mathrm{C}$ por 24 horas.

Após o enriquecimento seletivo, adicionou-se $1 \mathrm{~mL}$ do BLEB em um tubo estéril, procedendo-se a inativação dos microrganismos pela submersão desse tubo em banho de água fervente por 5 minutos. $O$ caldo inativado foi então resfriado a $25-37^{\circ} \mathrm{C}$ e utilizado na inoculação do teste, transferindo-se $0,1 \mathrm{~mL}$ para a área circular do kit. Decorridos 10 minutos de incubação à temperatura ambiente, procedeu-se a leitura do resultado.

\subsubsection{Staphylococcus coagulase-positiva}

Para a contagem presuntiva de Staphylococcus coagulase-positiva, utilizou-se o método de contagem direta em placas, com semeadura em superfície e espalhamento com alça de Drigalsky (Figura 6), descrito em Silva et al. (2001).

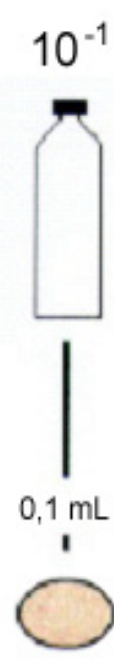

BPA

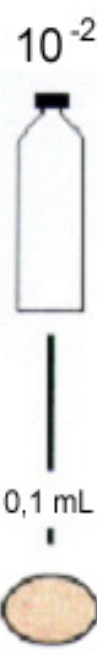

BPA

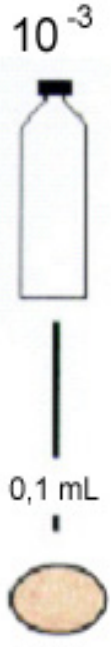

BPA
Estufa $35-37^{\circ} \mathrm{C} / 48 \mathrm{~h}$

Figura 6 - Esquema da contagem presuntiva de Staphylococcus coagulase-positiva. 
Alíquotas de $0,1 \mathrm{~mL}$ das diluições $10^{-1}, 10^{-2}$ e $10^{-3}$ foram inoculadas na superfície de placas contendo o meio Baird-Parker Ágar (BPA), previamente preparadas. $\mathrm{O}$ inóculo foi espalhado com uma alça de Drigalsky, até que o mesmo fosse totalmente absorvido pelo meio de cultivo. Após a secagem do inóculo, as placas foram invertidas e incubadas a $35-37^{\circ} \mathrm{C}$ por $24-48$ horas.

Recomendado para a contagem de Staphylococcus aureus em alimentos, o BPA caracteriza-se por ser um meio de cultura seletivo e diferencial, uma vez que combina o telurito de potássio, a glicina, o piruvato de sódio e o cloreto de lítio como agentes seletivos, além de utilizar a redução do telurito e a hidrólise da gema de ovo como características diferenciais (Hajdenwurcel, 1998).

Para a contagem presuntiva de Staphylococcus coagulase-positiva, selecionou-se placas contendo 20 a 200 colônias e, com o auxílio de um microscópio estereoscópico, foram contadas as colônias típicas, ou seja, colônias negras, circulares, brilhantes, pequenas, lisas, convexas, com bordas perfeitas e rodeadas por uma zona opaca e/ou um halo transparente. Eventualmente, colônias atípicas porém suspeitas também foram contadas.

Para a confirmação, algumas dessas colônias suspeitas foram selecionadas e submetidas ao teste de atividade de coagulase (Figura 7), descrito a seguir.

\subsection{Teste de coagulase}

Inoculou-se colônias suspeitas de Staphylococcus coagulase-positiva em tubos contendo $2 \mathrm{~mL}$ de Caldo Infusão Cérebro Coração (BHI), que foram incubados a $35-37^{\circ} \mathrm{C}$ por 24 horas. Após a incubação, transferiu-se $0,2 \mathrm{~mL}$ das culturas formadas para tubos com dimensões de $10 \times 100 \mathrm{~mm}$, estéreis, e adicionou-se 0,5 mL de Coagu-Plasma com EDTA, misturando-se com movimentos de rotação e sem agitação dos tubos. Incubou-se novamente a 35- 
$37^{\circ} \mathrm{C}$ e observou-se periodicamente, durante um intervalo de 6 horas, a formação ou não de coágulo.

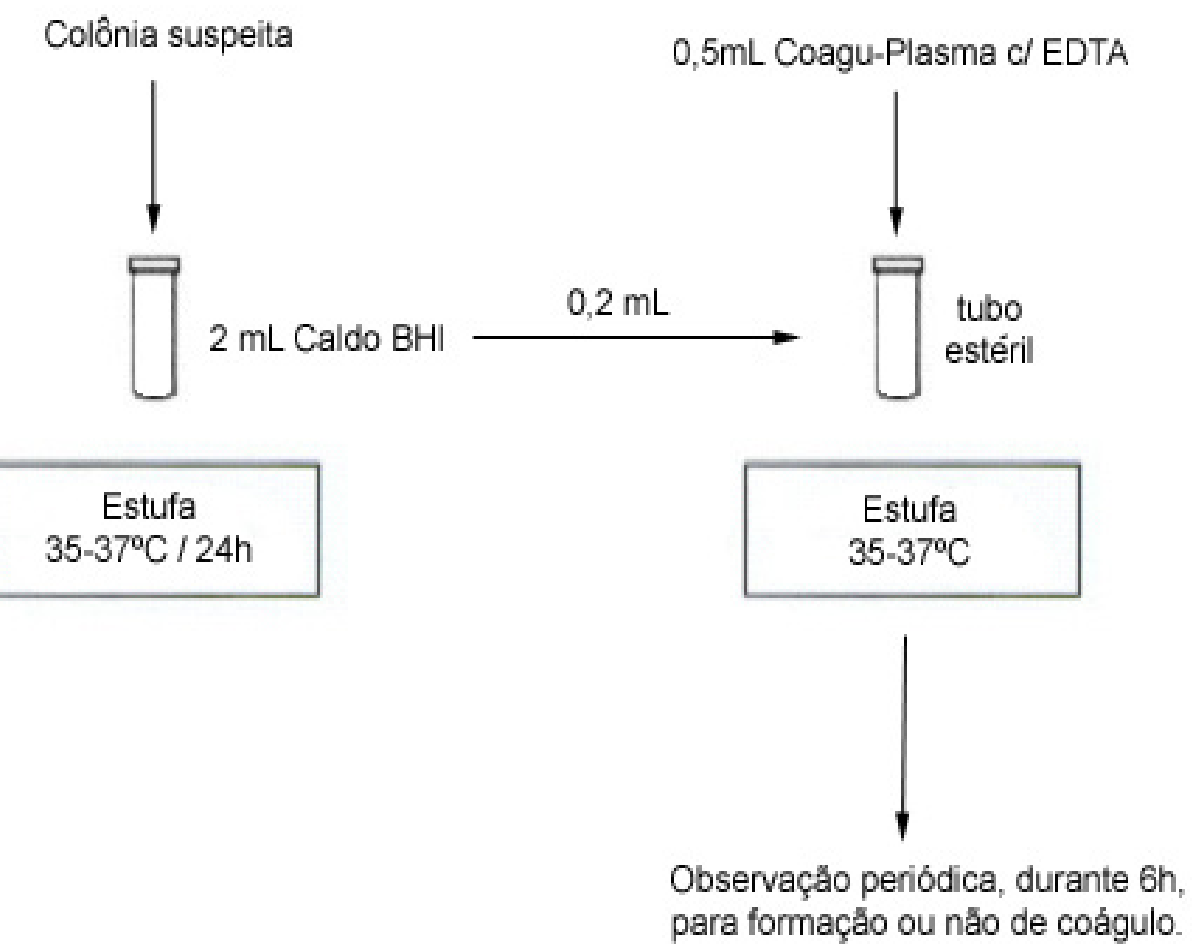

Figura 7 - Esquema do teste de atividade de coagulase.

\subsubsection{Determinação eletrométrica do pH}

Para a determinação do $\mathrm{pH}$, utilizou-se o método descrito por Pregnolatto \& Pregnolatto (1985). Pesou-se $10 \mathrm{~g}$ de amostra e transferiu-se para um erlenmeyer de $250 \mathrm{~mL}$ contendo $100 \mathrm{~mL}$ de água a $25^{\circ} \mathrm{C}$, previamente fervida, esmagando-se a amostra com o auxílio de um bastão. O conteúdo desse frasco foi então agitado ocasionalmente durante 30 minutos. A suspensão foi deixada em repouso por 10 minutos e o líquido sobrenadante foi transferido para um 
frasco seco, sendo a determinação do $\mathrm{pH}$ realizada imediatamente em potenciômetro da marca Digimed, modelo DMPH-1. 


\section{RESULTADOS E DISCUSSÃO}

Os valores obtidos na determinação de pH em amostras de mussarela de leite de búfala, das marcas com soro (A) e sem soro e a vácuo (B), são encontrados na Tabela 5.

Tabela 5. Valores de pH em amostras de mussarela de leite de búfala.

\begin{tabular}{ccc}
\hline Coleta & Marca A & Marca B \\
\hline 1 & 4,8 & 4,8 \\
2 & 5,0 & 5,0 \\
3 & 5,1 & 5,5 \\
4 & 4,9 & 5,5 \\
5 & 5,0 & 4,8 \\
6 & 4,4 & 5,0 \\
7 & 4,8 & 5,0 \\
8 & 4,6 & 5,0 \\
9 & 4,7 & 5,2 \\
10 & 4,9 & 4,9 \\
11 & 5,3 & 4,9 \\
12 & 5,4 & 5,0 \\
Média & 4,9 & 5,0 \\
\hline
\end{tabular}

Marca $A=$ Embalagem com soro

Marca $B=$ Embalagem sem soro e a vácuo

Como pode ser observado na Tabela 5, ambas as marcas apresentaram valores de $\mathrm{pH}$ inferiores, na maioria das vezes, aos mencionados por Ferrara \& Intrieri (1975) (5,5-5,8), por Bonassi et al. (1982) $(5,48)$, em mussarela de leite de búfala logo após a sua fabricação, e por Cortesi et al. (1997) $(5,54$ e 5,63), 
nesse mesmo tipo de queijo, porém armazenado por 7 dias a $6^{\circ} \mathrm{C}$ em salmoura. Os valores obtidos somente se aproximaram dos valores citados por esses autores em uma determinação da marca $\mathrm{A}$, onde o valor de $\mathrm{pH}$ apresentado foi de 5,4, e em duas determinações da marca $B$, onde o pH atingiu valores de 5,5.

Entre os fatores que favorecem o crescimento da maioria dos microrganismos nos alimentos está o valor de pH entre 6,0 e 7,0. No entanto, sabe-se que alguns microrganismos podem se desenvolver nos valores de $\mathrm{pH}$ encontrados nos queijos analisados, incluindo-se aí até alguns microrganismos patogênicos, como é o caso de Listeria monocytogenes, Salmonella spp. e Staphylococcus coagulase-positiva. Os valores de $\mathrm{pH}$ obtidos possibilitam, inclusive, a produção de toxinas por esse último.

$\mathrm{O}$ RIISPOA nada menciona quanto ao valor de $\mathrm{pH}$ adequado para o queijo tipo mussarela (Brasil, 1980). A legislação estadual, através do Código Sanitário, apenas se limita a estabelecer teores máximo de umidade $(58 \% \mathrm{p} / \mathrm{p})$ e mínimo de gordura (28\% p/p) para esse tipo de queijo (São Paulo, 1992).

De acordo com Pregnolatto \& Pregnolatto (1985), o valor de pH pode advertir sobre o estado de conservação de um produto alimentício, uma vez que indica a concentração de íons de hidrogênio livres, alterada quase sempre por processos de decomposição, seja por hidrólise, oxidação ou fermentação. Além disso, sabe-se que valores de $\mathrm{pH}$ muito reduzidos podem indicar a ocorrência de desenvolvimento microbiano e, conseqüentemente, a potencial presença de microrganismos deterioradores, patogênicos e/ou toxinas.

Embora o crescimento microbiano tenha sido maior na marca $A$, como será comentado com mais detalhes posteriormente, notou-se que as duas marcas apresentaram valores médios de $\mathrm{pH}$ bem próximos entre si.

Os resultados das análises microbiológicas realizadas nas duas marcas de mussarela de leite de búfala, em três repetições analíticas por coleta, são apresentados nas Tabelas 6 a 8.

Os resultados das determinações do NMP de coliformes totais e fecais são encontrados nas Tabelas 6 e 7. 
Tabela 6. Número mais provável (NMP) de coliformes totais por grama de amostra de mussarela de leite de búfala.

\begin{tabular}{|c|c|c|c|c|c|c|}
\hline \multirow{3}{*}{ Coleta } & \multicolumn{3}{|c|}{ Marca A } & \multicolumn{3}{|c|}{ Marca B } \\
\hline & \multicolumn{3}{|c|}{ Repetição analítica } & \multicolumn{3}{|c|}{ Repetição analítica } \\
\hline & I & II & III & 1 & II & 111 \\
\hline 1 & $>1,10 \times 10^{2}$ & $>1,10 \times 10^{2}$ & $>1,10 \times 10^{2}$ & 2,90 & $4,60 \times 10$ & 0,91 \\
\hline 2 & $>1,10 \times 10^{2}$ & $>1,10 \times 10^{2}$ & $>1,10 \times 10^{2}$ & 0,91 & 2,30 & 2,30 \\
\hline 3 & $>1,10 \times 10^{2}$ & $>1,10 \times 10^{2}$ & $>1,10 \times 10^{2}$ & $2,40 \times 10$ & 2,30 & $4,60 \times 10$ \\
\hline 4 & $>1,10 \times 10^{2}$ & $>1,10 \times 10^{2}$ & $>1,10 \times 10^{2}$ & $1,10 \times 10^{2}$ & $1,10 \times 10^{2}$ & $1,10 \times 10^{2}$ \\
\hline 5 & $>1,10 \times 10^{2}$ & $>1,10 \times 10^{2}$ & $>1,10 \times 10^{2}$ & 9,30 & 0,36 & $<0,30$ \\
\hline 6 & $>1,10 \times 10^{2}$ & $>1,10 \times 10^{2}$ & $>1,10 \times 10^{2}$ & $1,10 \times 10^{2}$ & $1,10 \times 10^{2}$ & $4,60 \times 10$ \\
\hline 7 & $>1,10 \times 10^{2}$ & $>1,10 \times 10^{2}$ & $>1,10 \times 10^{2}$ & 0,36 & 0,36 & $1,10 \times 10^{2}$ \\
\hline 8 & $>1,10 \times 10^{2}$ & $>1,10 \times 10^{2}$ & $>1,10 \times 10^{2}$ & $1,10 \times 10^{2}$ & $1,10 \times 10^{2}$ & $1,10 \times 10^{2}$ \\
\hline 9 & 2,30 & $2,40 \times 10$ & $1,10 \times 10^{2}$ & $1,10 \times 10^{2}$ & 7,50 & $4,60 \times 10$ \\
\hline 10 & $>1,10 \times 10^{2}$ & $>1,10 \times 10^{2}$ & $>1,10 \times 10^{2}$ & $<0,30$ & $<0,30$ & 0,30 \\
\hline 11 & $4,60 \times 10$ & 2,30 & 2,30 & 0,91 & 2,30 & $1,10 \times 10^{2}$ \\
\hline 12 & $>1,10 \times 10^{2}$ & $>1,10 \times 10^{2}$ & $>1,10 \times 10^{2}$ & 9,30 & $1,10 \times 10^{2}$ & $1,10 \times 10^{2}$ \\
\hline
\end{tabular}

Marca $A=$ Embalagem com soro

Marca $B=$ Embalagem sem soro e a vácuo 
Tabela 7. Número mais provável (NMP) de coliformes fecais por grama de amostra de mussarela de leite de búfala.

\begin{tabular}{|c|c|c|c|c|c|c|}
\hline \multirow{3}{*}{ Coleta } & \multicolumn{3}{|c|}{ Marca A } & \multicolumn{3}{|c|}{ Marca B } \\
\hline & \multicolumn{3}{|c|}{ Repetição analítica } & \multicolumn{3}{|c|}{ Repetição analítica } \\
\hline & I & II & I I I & I & II & I I I \\
\hline 1 & $2,90 \times 10$ & 9,30 & $2,10 \times 10$ & $<0,30$ & $<0,30$ & $<0,30$ \\
\hline 2 & 1,10 & $1,50 \times 10$ & 3,60 & $<0,30$ & $<0,30$ & 0,36 \\
\hline 3 & 9,30 & $2,40 \times 10$ & 9,30 & 0,36 & $<0,30$ & $4,60 \times 10$ \\
\hline 4 & $1,10 \times 10^{2}$ & 4,30 & $1,50 \times 10$ & $1,10 \times 10^{2}$ & $1,10 \times 10^{2}$ & $1,10 \times 10^{2}$ \\
\hline 5 & $1,10 \times 10^{2}$ & $1,10 \times 10^{2}$ & $1,10 \times 10^{2}$ & $<0,30$ & $<0,30$ & $<0,30$ \\
\hline 6 & 3,50 & $1,10 \times 10^{2}$ & $2,90 \times 10$ & $<0,30$ & $<0,30$ & $<0,30$ \\
\hline 7 & 2,90 & $1,50 \times 10$ & 3,60 & $<0,30$ & $<0,30$ & 3,50 \\
\hline 8 & $1,10 \times 10^{2}$ & $2,90 \times 10$ & $1,10 \times 10^{2}$ & $<0,30$ & $<0,30$ & $<0,30$ \\
\hline 9 & $<0,30$ & 9,30 & $1,10 \times 10^{2}$ & $4,60 \times 10$ & $<0,30$ & 0,91 \\
\hline 10 & 4,20 & 4,20 & $1,10 \times 10^{2}$ & $<0,30$ & $<0,30$ & $<0,30$ \\
\hline 11 & 0,73 & 0,91 & 2,30 & $<0,30$ & $<0,30$ & 2,30 \\
\hline 12 & $1,10 \times 10^{2}$ & $4,60 \times 10$ & $1,50 \times 10$ & 0,36 & $<0,30$ & 4,30 \\
\hline
\end{tabular}

Marca $A=$ Embalagem com soro

Marca $B=$ Embalagem sem soro e a vácuo 
Com base na quantidade de coliformes fecais encontrada nas amostras, pode-se afirmar que ambas as marcas encontram-se dentro do padrão microbiológico estabelecido pela Resolução RDC nํ 12 de 02/01/01, a qual fixa $5,0 \times 10^{3}$ como sendo o NMP de coliformes a $45^{\circ} \mathrm{C} / \mathrm{g}$ tolerável na mussarela de leite de búfala. Ainda no que se refere a coliformes fecais, todos os queijos amostrados apresentaram valores inferiores ao obtido por Silva et al. (1999), os quais encontraram uma população média de $1,06 \times 10^{3}$ coliformes fecais em massa logo após a filagem, em um processo de fabricação de mussarela a partir de leite cru de búfala, diferentemente dos processos de elaboração dos queijos analisados no presente trabalho, os quais foram obtidos a partir de leite pasteurizado.

Já em outro trabalho, porém também utilizando leite cru de búfala para a elaboração de mussarela, Silva et al. (1997) obtiveram populações médias de 1,90 x 10 e 2,40 coliformes fecais, em massas logo após filagens mecanizada e manual, respectivamente. Esses autores ainda analisaram, no mesmo trabalho, esse grupo de microrganismos no produto final, previamente à sua embalagem, com moldagens manual e mecanizada, e encontraram populações médias de $9,26 \times 10$ e 2,98 coliformes fecais, respectivamente.

Cortesi et al. (1997) não detectaram Escherichia coli em mussarela, elaborada com leite cru de búfala e armazenada sob refrigeração $\left(6^{\circ} \mathrm{C}\right)$ por 7 dias em salmoura. No entanto, ao analisarem o grupo das enterobactérias, encontraram contagens de até $1,80 \times 10^{4} \mathrm{UFC} / \mathrm{g}$. Os autores ainda observaram uma alta contaminação por coliformes totais nesse produto, sendo $>10^{4} \mathrm{o}$ NMP/g encontrado. Resultados elevados para esse grupo de microrganismos também foram encontrados por Silva et al. (1997), em massa logo após a filagem $\left(1,54 \times 10^{3} / \mathrm{g}\right)$ e já no produto final previamente à sua embalagem $(3,57$ x $10^{3} / \mathrm{g}$ ), em uma linha de produção manual, e por Silva et al. (1999), em massa logo após a filagem $\left(3,49 \times 10^{3} / \mathrm{g}\right)$.

A legislação brasileira não estabelece limites de tolerância para coliformes totais em mussarela de leite de búfala. Entretanto, a contagem de 
microrganismos do grupo coliforme, sobretudo os de origem fecal, indica as condições de higiene em que os queijos foram elaborados, uma vez que tais microrganismos, comumente encontrados no leite cru, são geralmente destruídos pela pasteurização.

Normalmente, a presença de coliformes fecais em alimentos é relacionada com contaminação fecal de animais e do homem, apesar da ocorrência de Escherichia coli ser mais adequada para tais conclusões.

Apesar dos queijos analisados estarem em conformidade com a legislação, a presença de indicadores de contaminação fecal em ambas as marcas, embora em maior quantidade na marca $A$, provavelmente revela condições inadequadas de higiene durante a fabricação dos queijos, ficando claro que os mesmos podem estar sendo expostos à contaminação por microrganismos indesejados, inclusive patogênicos. Além disso, deve-se ressaltar a importância de algumas linhagens de Escherichia coli como enteropatógenos potenciais.

As Figuras 8 e 9 ilustram a distribuição percentual das populações de coliformes totais e fecais (NMP/g), respectivamente, em amostras de mussarela de leite de búfala comercializadas em embalagem com soro (marca $A$ ) e sem soro e a vácuo (marca B). 

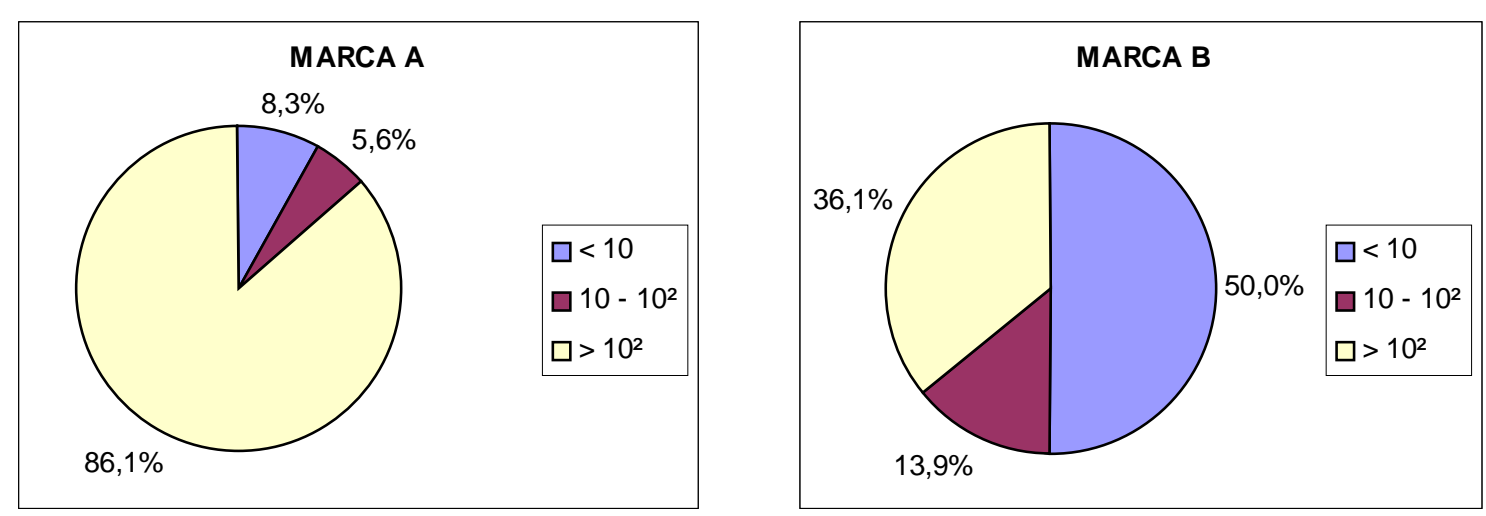

Figura 8 - Distribuição percentual da população de coliformes totais (NMP/g) em amostras de mussarela de leite de búfala, comercializadas em embalagem com soro (marca A) e sem soro e a vácuo (marca B).
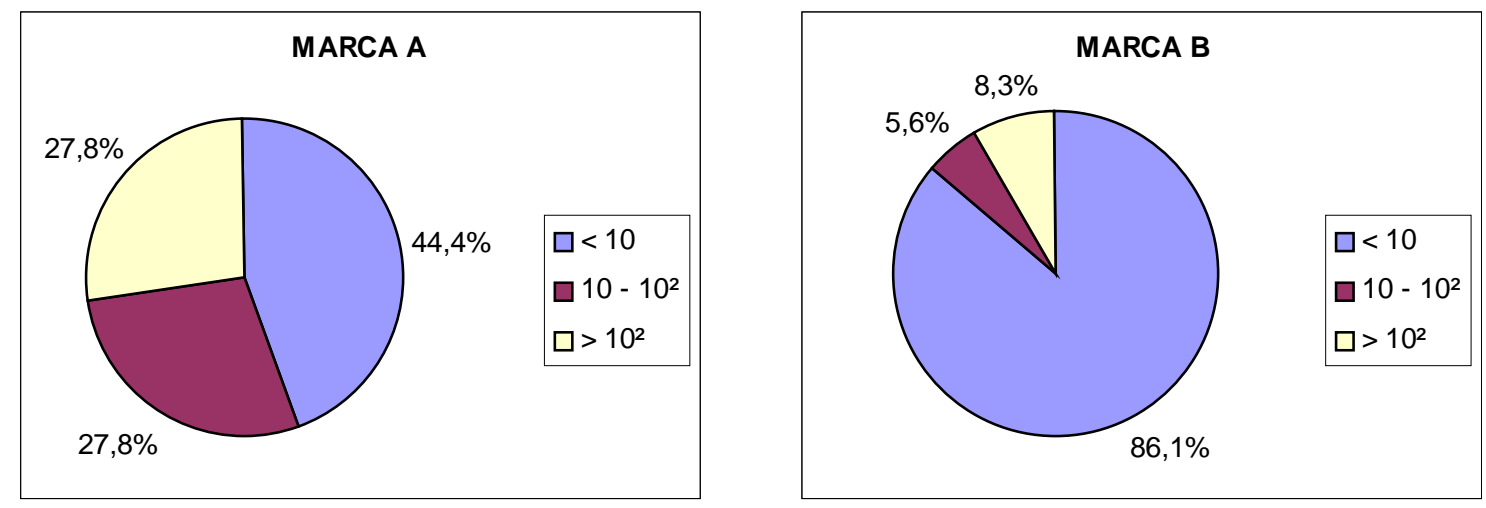

Figura 9 - Distribuição percentual da população de coliformes fecais (NMP/g) em amostras de mussarela de leite de búfala, comercializadas em embalagem com soro (marca A) e sem soro e a vácuo (marca B). 
Como pode ser observado nas Figuras 8 e 9, a contaminação na marca A mostrou-se superior, na maioria das vezes, à encontrada na marca B. Além disso, em $86,1 \%$ das determinações, o NMP de coliformes totais/g apresentado pela marca $A$ foi $>10^{2}$. Tais níveis de contaminação apareceram em $36,1 \%$ das determinações na marca B. Já para coliformes fecais, populações maiores que $10^{2}$ foram encontradas em 27,8 e $8,3 \%$ das determinações nas marcas $A$ e $B$, respectivamente.

A alta carga microbiana em produtos que já sofreram pasteurização pode ser explicada pela utilização de matéria-prima altamente contaminada. Segundo Abele (1966), a alta contaminação em leite pasteurizado pode ser justificada, entre outras causas, pela presença de uma grande população de coliformes no leite cru, cuja destruição através de pasteurização eficaz é de 99,5\%, permitindo ainda a sobrevivência de um número de microrganismos suficientemente grande para dar resultado positivo na análise. Isso pode ter acontecido com as amostras de queijo da marca $A$, onde uma maior contaminação pode ser devida a níveis elevados de coliformes no leite cru, com permanência de um certo número dessas bactérias viáveis no leite pasteurizado e conseqüentemente no produto final. Também não se descarta a possibilidade de recontaminação após tratamento térmico e filagem do produto.

Os resultados da pesquisa de Salmonella spp. mostraram que todas as amostras de mussarela de leite de búfala analisadas foram negativas para essa bactéria, concordando com os resultados obtidos por Silva et al. (1999) em massa logo após a filagem, em um processo de fabricação de mussarela a partir de leite cru de búfala. Portanto, pode-se afirmar que ambas as marcas encontram-se em conformidade com o padrão microbiológico estabelecido pela Resolução RDC n- 12 de 02/01/01, a qual determina a ausência desse microrganismo em 25 gramas do produto analisado.

No entanto, Silva et al. (1997) observaram a presença de Salmonella spp. em 6,25\% (1/16) das determinações realizadas em mussarela de leite de 
búfala, previamente à sua embalagem, produzida a partir de leite cru em um sistema totalmente manual.

Cortesi et al. (1997) estudaram o comportamento da Salmonella senftenberg, inoculada em diferentes níveis no leite cru de búfala, durante a tradicional manufatura da mussarela e a estocagem a $6^{\circ} \mathrm{C}$ por 7 dias. $\mathrm{O}$ microrganismo cresceu durante a maturação da coalhada, foi reduzido pela filagem, porém ainda sobreviveu no queijo elaborado com o leite que recebeu o maior inóculo. O conteúdo de gordura da coalhada e o aquecimento desigual da massa durante a filagem podem ter contribuído para a sobrevivência da Salmonella spp. No entanto, o processo de manufatura da mussarela assegurou a destruição da Salmonella senftenberg, quando inoculada no leite em níveis de 2,0 × $10^{2} \mathrm{UFC} / \mathrm{mL}$. De acordo com os autores, tais níveis somente são atingidos em leite contaminado naturalmente quando ocorrem falhas grosseiras nas condições sanitárias dos animais e nas medidas higiênicas durante a ordenha, a estocagem e o transporte do leite.

De acordo com os resultados da pesquisa de Listeria spp., essa bactéria mostrou-se ausente em todas as amostras de mussarela de leite de búfala analisadas. Considera-se, portanto, que ambas as marcas encontram-se em acordo com o padrão microbiológico estabelecido pela Resolução RDC nํㅜ 12 de 02/01/01, a qual determina a ausência desse microrganismo em 25 gramas do produto analisado.

Tais resultados concordam com aqueles obtidos por Silva et al. (1997), os quais não detectaram Listeria monocytogenes em queijos previamente à embalagem, elaborados com leite cru de búfala em sistemas manual e parcialmente mecanizado.

Harvey \& Gilmour (1992) também não detectaram Listeria monocytogenes em amostras de queijos variados. Entretanto, a Listeria seeligeri foi encontrada em 1 das 33 amostras de queijo mole examinadas.

Silva et al. (1998) estudaram a incidência de Listeria spp. em diferentes tipos de queijo, incluindo Minas frescal, ricota, gorgonzola, brie, cheddar, 
camembert e roquefort. Das 103 amostras de queijo analisadas, 11 (10,68\%) estavam contaminadas por Listeria monocytogenes, 13 (12,62\%) por Listeria innocua, 6 (5,83\%) por Listeria grayi e 1 (0,97\%) por Listeria welshimeri. Ainda de acordo com os autores, a maior incidência de Listeria monocytogenes foi observada em queijo Minas frescal caseiro, seguido por queijos maturados (gorgonzola, brie e roquefort) e Minas frescal e ricota industrialmente elaborados.

A Listeria monocytogenes corresponde a um contaminante amplamente distribuído no ambiente, sendo o agente etiológico da listeriose em diferentes animais. Sua transmissão ao homem pode se dar através da contaminação dos alimentos em qualquer ponto da cadeia alimentar, ocasionando a listeriose humana.

Até pouco tempo, esse microrganismo não era considerado como um importante patógeno transmitido através dos alimentos, não recebendo muita atenção por parte da indústria alimentícia. Porém, os casos de listeriose veiculados por alimentos no início da década de 80 , como aqueles reportados por Bell \& Kyriakides (1998), despertaram para a gravidade dessa enfermidade, a qual apresenta um alto índice de mortalidade, levando-o a ser considerado como um patógeno emergente.

Entre os fatores que aumentam a probabilidade de um alimento ser implicado em um surto de listeriose, esses autores citaram o uso de ingredientes crus, a adoção de formulação que permite o crescimento do microrganismo, o armazenamento refrigerado, uma vez que a Listeria monocytogenes cresce sob essas condições, e o tempo de conservação prolongado (maior que 10 dias). Segundo esses autores, os produtos lácteos são destacados como alimentos comumente implicados em surtos de listeriose.

Embora Listeria spp. não tenha sido detectada nas amostras analisadas nesse estudo, sabe-se que esse microrganismo pode estar presente nos alimentos em baixas concentrações e não ser detectado facilmente pelos métodos de isolamento. Além disso, deve-se enfatizar que a maioria dos 
queijos analisados apresentou valores de $\mathrm{pH}$ que não inibiriam o desenvolvimento desse microrganismo, se presente nesses queijos. O armazenamento refrigerado da mussarela de leite de búfala também não evitaria o crescimento de Listeria monocytogenes, por se tratar de um microrganismo psicrotrófico.

Os resultados da contagem de Staphylococcus coagulase-positiva são encontrados na Tabela 8. 
Tabela 8. Contagem de Staphylococcus coagulase-positiva (UFC/g) em amostras de mussarela de leite de búfala.

\begin{tabular}{|c|c|c|c|c|c|c|}
\hline \multirow{3}{*}{ Coleta } & \multicolumn{3}{|c|}{ Marca A } & \multicolumn{3}{|c|}{ Marca B } \\
\hline & \multicolumn{3}{|c|}{ Repetição analítica } & \multicolumn{3}{|c|}{ Repetição analítica } \\
\hline & I & 11 & 111 & I & 11 & 111 \\
\hline 1 & $<10^{2}$ & $<10^{2}$ & $<10^{2}$ & $<10^{2}$ & $<10^{2}$ & $<10^{2}$ \\
\hline 2 & $<10^{2}$ & $<10^{2}$ & $<10^{2}$ & $<10^{2}$ & $<10^{2}$ & $<10^{2}$ \\
\hline 3 & $<10^{2}$ & $<10^{2}$ & $<10^{2}$ & $<10^{2}$ & $<10^{2}$ & $<10^{2}$ \\
\hline 4 & $<10^{2}$ & $<10^{2}$ & $<10^{2}$ & $<10^{2}$ & $<10^{2}$ & $<10^{2}$ \\
\hline 5 & $<10^{2}$ & $<10^{2}$ & $<10^{2}$ & $<10^{2}$ & $<10^{2}$ & $<10^{2}$ \\
\hline 6 & $<10^{2}$ & $<10^{2}$ & $<10^{2}$ & $<10^{2}$ & $<10^{2}$ & $<10^{2}$ \\
\hline 7 & $<10^{2}$ & $<10^{2}$ & $<10^{2}$ & $<10^{2}$ & $<10^{2}$ & $<10^{2}$ \\
\hline 8 & $<10^{2}$ & $<10^{2}$ & $<10^{2}$ & $<10^{2}$ & $<10^{2}$ & $<10^{2}$ \\
\hline 9 & $<10^{2}$ & $<10^{2}$ & $<10^{2}$ & $<10^{2}$ & $<10^{2}$ & $<10^{2}$ \\
\hline 10 & $<10^{2}$ & $<10^{2}$ & $<10^{2}$ & $<10^{2}$ & $<10^{2}$ & $<10^{2}$ \\
\hline 11 & $<10^{2}$ & $<10^{2}$ & $<10^{2}$ & $<10^{2}$ & $<10^{2}$ & $<10^{2}$ \\
\hline 12 & $<10^{2}$ & $<10^{2}$ & $<10^{2}$ & $<10^{2}$ & $<10^{2}$ & $<10^{2}$ \\
\hline
\end{tabular}

Marca $A=$ Embalagem com soro

Marca $B=$ Embalagem sem soro e a vácuo 
Como pode ser observado na Tabela 8 , todos os queijos analisados apresentaram contagens menores que $10^{2} \mathrm{UFC} / g$ de amostra, enquadrando-se, portanto, no padrão microbiológico estabelecido pela Resolução RDC $\mathrm{n}^{0} 12 \mathrm{de}$ 02/01/01, a qual tolera uma contagem de até $10^{3} \mathrm{UFC} / \mathrm{g}$ de amostra para esse microrganismo. Cortesi et al. (1997) também não detectaram o Staphylococcus coagulase-positiva em mussarela, elaborada com leite cru de búfala e armazenada a $6^{\circ} \mathrm{C}$ por 7 dias em salmoura.

Os queijos tipo mussarela obtidos a partir de leite cru de búfala por Silva et al. (1997) apresentaram, previamente à embalagem, contagens médias de $1,95 \times 10^{2}$ e $4,38 \times 10 \mathrm{UFC} / g$ de amostra para Staphylococcus coagulasepositiva, em processos de fabricação manual e parcialmente mecanizado, respectivamente, sendo que no processo manual foram observadas contagens de até $2,0 \times 10^{3} \mathrm{UFC} / \mathrm{g}$ de amostra.

Embora a eficiência da filagem seja comparada à da pasteurização no trabalho de Silva et al. (1999), em um processo de fabricação de mussarela a partir de leite cru de búfala, deve-se considerar que o Staphylococcus coagulase-positiva não foi eliminado, através da filagem, em 3 amostras de massa de queijo filada. No mesmo trabalho, os autores ainda verificaram que outras 3 amostras resultaram positivas para esse microrganismo apenas após o processo de filagem, indicando provável contaminação pelo manipulador.

O Staphylococcus spp. foi isolado como um dos principais agentes etiológicos da mastite bubalina em diversos trabalhos (Brinez et al., 2000; Costa et al., 1997; Paranjape \& Das, 1986). Além disso, o homem e outros animais constituem o principal reservatório de Staphylococcus aureus, estando presente na mucosa nasal, garganta, cabelo e pele de mais de $50 \%$ da população humana. Ainda são responsáveis por infecções, desde lesões na pele até infecções generalizadas e sistêmicas. A ampla disseminação do Staphylococcus aureus no ambiente justifica a freqüente presença desse microrganismo nos alimentos, principalmente naqueles submetidos à intensa manipulação sob condições precárias de higiene. 
Por ser um produto que exige muita manipulação na sua fabricação, a mussarela de leite de búfala acaba se tornando muito vulnerável à contaminação por esse microrganismo. Além disso, alimentos ricos em proteína servem como um excelente meio de cultura para o seu desenvolvimento. De acordo com McKane \& Kandel (1996), a manutenção de alimentos contaminados em temperaturas entre 20 e $35^{\circ} \mathrm{C}$ por várias horas permite a multiplicação de Staphylococcus coagulase-positiva e a liberação de toxinas suficiente para gerar os sintomas de intoxicação. Dessa forma, torna-se fundamental o controle das condições as quais o produto final é submetido após a fabricação, principalmente durante a sua distribuição e comercialização.

$\mathrm{O}$ armazenamento refrigerado, durante essas fases, apresenta-se como um forte aliado à preservação da qualidade dos alimentos perecíveis, entre os quais se destaca a mussarela de leite de búfala. A refrigeração mostra-se importante não somente para o controle do desenvolvimento de Staphylococcus coagulase-positiva nos alimentos, como também de outros microrganismos patogênicos e deterioradores.

A interrupção da cadeia do frio deve ser evitada, durante a distribuição e comercialização da mussarela de leite de búfala, eliminando-se oscilações de temperatura nessas fases, visando garantir a manutenção da qualidade desse queijo.

As gôndolas dos estabelecimentos comerciais, nas quais as amostras analisadas no presente trabalho foram adquiridas, mostraram uma variação de temperatura entre 7 e $8^{\circ} \mathrm{C}$. Esses resultados demonstraram boas condições de armazenamento dos queijos durante a comercialização. Entretanto, nada se pode afirmar a respeito dessas condições durante a distribuição dos queijos, uma vez que essa fase não foi monitorada.

Com base nos resultados obtidos nas análises microbiológicas efetuadas nesse trabalho, pode-se afirmar que as duas marcas de mussarela de leite de búfala encontram-se em acordo com os padrões microbiológicos legais vigentes. 
Mesmo não se constatando a presença de microrganismos patogênicos em nenhuma das marcas de queijo analisadas, os resultados obtidos evidenciaram que a qualidade microbiológica do queijo comercializado em embalagem com soro (marca $A$ ) foi inferior à do oferecido em embalagem sem soro e a vácuo (marca $B$ ).

De acordo com Jay (1992), a capacidade de multiplicação dos microrganismos que estão presentes em um alimento depende de fatores extrínsecos, ou seja, das características do ambiente em que o mesmo se encontra, tais como umidade relativa, temperatura e composição química da atmosfera que envolve o alimento, como também de fatores intrínsecos ou características próprias do alimento, tais como atividade de água ( $\mathrm{Aa}$ ), acidez $(\mathrm{pH})$, potencial de oxi-redução $(\mathrm{Eh})$, composição química ou conteúdo de nutrientes, presença de fatores antimicrobianos naturais e estruturas biológicas.

Segundo Mucchetti et al. (1997), a estocagem do produto final em temperaturas inadequadas possibilita a solubilização de sólidos orgânicos no líquido que banha a mussarela, favorecendo o crescimento de microrganismos contaminantes presentes nesse líquido ou na superfície do queijo.

Dessa forma, a presença do soro pode estar atuando como um fator que favorece o desenvolvimento de microrganismos no produto da marca A. No entanto, estudos mais detalhados poderão ser conduzidos visando avaliar, com segurança, a influência da forma de acondicionamento dos queijos no seu grau de contaminação. De qualquer maneira, cuidados especiais na distribuição e na comercialização devem ser dispensados aos produtos embalados com soro, uma vez que esse tipo de acondicionamento contribui para a multiplicação de microrganismos presentes.

A ausência de positividade para alguns microrganismos patogênicos não garante a segurança dos produtos analisados, uma vez que coliformes fecais foram encontrados, revelando que os queijos podem estar sendo expostos a contaminações por outras enterobactérias, inclusive patogênicas, tais como 
Escherichia coli O157:H7, Shigella spp., Vibrio spp., Yersinia enterocolitica, entre outras.

Enfatiza-se, portanto, a importância do cumprimento das normas relativas às Boas Práticas de Fabricação, a fim de se obter produtos lácteos de qualidade superior, incluindo o controle sanitário do rebanho, a obtenção higiênica do leite, a conservação adequada do leite ordenhado, o controle higiênico-sanitário dos operadores, a utilização de leite pasteurizado e a limpeza e desinfecção adequada dos equipamentos e utensílios utilizados no processamento. 


\section{CONCLUSÕES}

- Todas as amostras de ambas as marcas de mussarela de leite de búfala analisadas enquadram-se nos padrões microbiológicos legais vigentes.

- Embora todas as amostras analisadas não tenham apresentado contaminação pelas bactérias patogênicas Salmonella spp., Listeria spp. e Staphylococcus spp., a presença de indicadores de contaminação fecal, em ambas as marcas, revela provavelmente condições inadequadas de higiene durante a manufatura dos queijos. Portanto, a implementação de melhores práticas de fabricação mostra-se pertinente, visando a obtenção de produtos lácteos de qualidade higiênico-sanitária superior.

- A qualidade microbiológica do queijo comercializado em embalagem com soro (marca $A$ ) foi inferior à do oferecido em embalagem sem soro e a vácuo (marca B), o que remete à necessidade de estudos mais detalhados, os quais poderão avaliar, com segurança, a influência da forma de acondicionamento dos queijos no seu grau de contaminação.

- Uma maior conscientização deve ocorrer, por parte dos produtores de mussarela de leite de búfala, sobre a importância de se evitar a prática, existente em algumas regiões, de utilização de leite não submetido a tratamento térmico na elaboração desse tipo de queijo. 


\section{REFERÊNCIAS BIBLIOGRÁFICAS}

ABELE, C.A. Controle dos microrganismos coliformes. Revista do Instituto de Laticínios Cândido Tostes, v.2, n.125, p.14-18, 1966.

AGÊNCIA NACIONAL DE VIGILÂNCIA SANITÁRIA (ANVISA). Resolução RDC no 12 de 02 de Janeiro de 2001. http:www.anvisa.gov.br (05 maio 2003)

ALMEIDA, M.O.L. de. O búfalo: situação mundial. In: O BúFALO e sua rentabilidade. Guaíba: Agropecuária, 1994. cap.1, p.11-15.

ANTUNES, L.A.F.; YABU, M.C.; SCHOLZ, M.B.S.; RAPACCI, M. Variações físico-químicas e sensoriais em misturas de leites bovino e bubalino. Revista do Instituto de Laticínios Cândido Tostes, v.43, n.259, p.20-22, 1988.

ANUÁRIO ESTATÍSTICO DO BRASIL - 1999, v.59, p.3-78, 2000.

ASSOCIAÇÃO BRASILEIRA DE NORMAS TÉCNICAS (ABNT). Bactérias coliformes totais, coliformes fecais e Escherichia coli em alimentos: determinação do número mais provável (NMP): MB-3463. Rio de Janeiro, 1991. $7 p$. 
BELL, C.; KYRIAKIDES, A. Listeria: una aproximación práctica al microorganismo y su control en los alimentos. 1.ed. Zaragoza: Acribia, 1998. cap.2, p.11-33: Brotes: causas y lecciones que deben aprenderse.

BERNARDES, W.; BERNARDES, O. Exploração leiteira de búfala. In: SAMARA, S.I.; DUTRA, I. dos S.; FRANCESCHINI, P.H.; MOLERO FILHO, J.R.; CHACUR, M.G.M. (Ed.). Sanidade e produtividade em búfalos. Jaboticabal: FUNEP, 1993. p.161-184.

BONASSI, I.A.; CARVALHO, J.B. de C.; VILLARES, J.B. Utilização do leite de búfala como matéria-prima para elaboração de queijo mozzarela. Archivos Latinoamericanos de Nutricion, v.32, n.4, p.903-912, 1982.

BRASIL. Ministério da Agricultura. Regulamento de inspeção industrial e sanitária de produtos de origem animal. Brasília, 1980. 166p.

BRINEZ, W.; MOLERO, E.; MONTIEL, C.; VAlBuenA, E.; CASTRO, G.; URDANETA, S. Quality parameters and more frequent bacteriological genus in buffaloes milk in the Mara county, Zulia state. Revista Cientifica: Facultad de Ciencias Veterinárias, v.10, n.4, p.346-352, 2000.

BUSANI, S.F.B. Matéria-prima. In: VAN DENDER, A.G.F. Utilização artesanal do leite de búfala. Campinas: ITAL, 1989. p.1-8. (ITAL. Manual técnico, 3)

CASTALDO, M.C. La bufala ed il suo típico prodotto: "La Mozzarela". Rivista di Zootecnia, v.32, n.7/8, p.203-208, 1960.

COCKRILL, W.R. O búfalo em ascensão: animal doméstico fundamental: criação, proteção e saúde animal. In: RAMOS, A. de A.; VILLARES, J.B.; MOURA, J.C. de (Ed.). Os búfalos. São Paulo: FEALQ, 1981. p.28-54. 
CONSALVO, F. Marketing aspects of mozzarella cheese in Italy. In: WORLD BUFFALO CONGRESS, 5., Caserta, 1997. Proceedings. Caserta: s.ed., 1997. p.157-166.

COPPOLA, S.; PARENTE, E.; DUMONETET, S.; LA PECCERELLA, A. The microflora of natural whey cultures utilized as starters in the manufacture of mozzarella cheese from water-buffalo milk. Lait, v.68, n.3, p.295-310, 1988.

CORTESI, M.L.; CITRO, A.; SARLI, T.; SANTORO, A.; MURRU, N.; PEPE, T.; DELL'ORFANO, G. Behaviour of Salmonella senftenberg during manufacture of buffalo mozzarella cheese: preliminary researchs. In: WORLD BUFFALO CONGRESS, 5., Caserta, 1997. Proceedings. Caserta: s.ed., 1997. p.266-271.

COSTA, E.O. da; GARINO JÚNIOR, F.; WATANABE, E.T.; RIBEIRO, A.R.; VEZON, P.; BARUSELLI, P.S.; PASKE, A. Study of mastitis among ten dairy buffaloes herds (Bubalus bubalis) in the vale do Ribeira (Ribeira river valley) São Paulo, Brazil. In: WORLD BUFFALO CONGRESS, 5., Caserta, 1997. Proceedings. Caserta: s.ed., 1997. p.635-638.

CUNHA NETO, O.C. da; OLIVEIRA, C.A.F. de. Aspectos da qualidade microbiológica do leite de búfala. Higiene Alimentar, v.17, n.110, p.18-23, 2003.

DE FRANCISCIS, G.; DI PABLO, R. Buffalo milk production. In: WORLD BUFFALO CONGRESS, 4., São Paulo, 1994. Proceedings. São Paulo: s.ed., 1994. v.1, p.137-146.

DIAZ, J.S. O búfalo e seu manejo sanitário. In: O BúFALO e sua rentabilidade. Guaíba: Agropecuária, 1994. cap.4, p.31-35. 
FAO. O búfalo. Brasília: Ministério da Agricultura; São Paulo: Associação Brasileira de Criadores de Búfalos, 1991. 320p. (FAO. Produção Animal e Saúde, 4)

FAO PRODUCTION YEARBOOK - 2000, v.54, p.211, 2002.

FERNANDES, A.G.; MARTINS, J.F.P. Fabricação de requeijão cremoso a partir de massa obtida por precipitação ácida a quente de leite de búfala e de vaca. Revista do Instituto de Laticínios Cândido Tostes, v.35, n.212, p.7-13, 1980.

FERRARA, B.; INTRIERI, F. Características e uso do leite de búfala. II. Revista do Instituto de Laticínios Cândido Tostes, v.30, n.178, p.27-35, 1975.

FERREIRA, T.A.; GUINART, T. de C.; LAICINI, Z.M.; MURTA, P.H.G. Características do leite de búfala e seus derivados. Leite \& Derivados, v.4, n.22, p.16-20, 1995.

FONSECA, W. Búfalo: estudo e comportamento. São Paulo: Ícone, 1987. $213 p$.

FOX, P.F.; GUINEE, T.P. Italian cheeses. In: FOX, P.F. (Ed.). Cheese: chemistry, physycs and microbiology. New York: Elsevier Applied Science, 1987. v.2, cap.7, p.221-255.

FRANZOLIN NETO, R. Perspectivas da criação de búfalos no Brasil. In: SAMARA, S.I.; DUTRA, I. dos S.; FRANCESCHINI, P.H.; MOLERO FILHO, J.R.; CHACUR, M.G.M. (Ed.). Sanidade e produtividade em búfalos. Jaboticabal: FUNEP, 1993. p.1-16. 
FURTADO, M.M. Composição centesimal do leite de búfala na zona da mata mineira. Revista do Instituto de Laticínios Cândido Tostes, v.35, n.211, p.43-47, 1980a.

FURTADO, M.M. Leite de búfala: estudo da fabricação do queijo azul. Revista do Instituto de Laticínios Cândido Tostes, v.35, n.207, p.23-28, 1980b.

GANGULI, N.C. Tecnología de la leche de búfala. Revista Mundial de Zootecnia, v.30, p.2-10, 1979.

HAJDENWURCEL, J.R. Atlas de microbiologia de alimentos. 1.ed. São Paulo: Fonte, 1998. v.1, cap.3, p.35-58: Microrganismos patogênicos.

HALBIG, C.R. Búfalo: carne e leite. In: O BÚFALO e sua rentabilidade. Guaíba: Agropecuária, 1994. cap.3, p.21-29.

HARVEY, J.; GILMOUR, A. Occurrence of Listeria species in raw milk and dairy products produced in Northern Ireland. Journal of Applied Bacteriology, v.72, n.2, p.119-125, 1992.

HOBBS, B.C.; ROBERTS, D. Toxinfecções e controle higiênico-sanitário de alimentos. São Paulo: Varela, 1993. cap.8, p.128-141: Deterioração e preservação.

HUHN, S.; HAJDENWURCEL, J.R.; MORAES, J.M. de; VARGAS, O.L. Qualidade microbiológica do leite cru obtido por meio de ordenha manual e mecânica e ao chegar à plataforma. Revista do Instituto de Laticínios Cândido Tostes, v.35, n.209, p.3-8, 1980. 
INTERNATIONAL COMMISSION ON MICROBIOLOGICAL SPECIFICATIONS FOR FOODS. Microorganismos de los alimentos: técnicas de análisis microbiológico. 2.ed. Zaragoza: Acribia, 1984. v.1, p.3-14: Microorganismos indicadores.

JAY, J.M. Microbiología moderna de los alimentos. 3.ed. Zaragoza: Acribia, 1992. cap.3, p.45-74: Parámetros intrínsecos y extrínsecos que influyen en el crecimiento de los microorganismos.

LANDGRAF, M. Controle do desenvolvimento microbiano nos alimentos. In: FRANCO, B.D.G. de M.; LANDGRAF, M. Microbiologia dos alimentos. São Paulo: Atheneu, 2000. cap.7, p.109-148.

LÜCK, H. Quality control in the dairy industry. In: ROBINSON, R.K. (Ed.). Dairy microbiology: the microbiology of milk products. London: Elsevier Applied Science, 1981. v.2, cap.7, p.279-324.

MACEDO, M.P.; WECHSLER, F.S.; RAMOS, A. de A.; AMARAL, J.B. do; SOUZA, J.C. de; RESENDE, F.D. de; OLIVEIRA, J.V. de. Composição físico-química e produção do leite de búfalas da raça Mediterrâneo no oeste do Estado de São Paulo. Revista Brasileira de Zootecnia, v.30, n.3, p.1084-1088, 2001.

McKANE, L.; KANDEL, J. Microbiology: essentials and applications. 2.ed. New York: Mc Graw-Hill, 1996. cap.22, p.564-601: Diseases acquired through the alimentary tract. 
MUCCHETTI, G.; CARMINATI, D.; ADDEO, F. Tradition and innovation in the manufacture of the traditional water buffalo mozzarella cheese produced in Campania. In: WORLD BUFFALO CONGRESS, 5., Caserta, 1997. Proceedings. Caserta: s.ed., 1997. p.173-181.

NASCIMENTO, C.; CARVALHO, L.O.M. Criação de búfalos: alimentação, manejo, melhoramento e instalações. Brasília: EMBRAPA, SPI, 1993. cap.1, p.1-9: Introdução.

NASCIMENTO, C.N.B. do; CARVALHO, L.O.D. de M.; LOURENÇO JÚNOR, J. de B. Importância do búfalo para a pecuária brasileira. In: RAMOS, A. de A.; VILLARES, J.B.; MOURA, J.C. de (Ed.). Os búfalos. São Paulo: FEALQ, 1981. p.73-118.

PARANJAPE, M.J.; DAS, A.M. Mastitis among buffalo population of Bombay: a bacteriological report. Indian Veterinary Journal, v.63, n.6, p.438-441, 1986.

PREGNOLATTO, W.; PREGNOLATTO, N.P. Normas analíticas do Instituto Adolfo Lutz. 3.ed. São Paulo: Instituto Adolfo Lutz, 1985. v.1, cap.4, p.1676: Determinações gerais.

SÃO PAULO (Estado). Código sanitário: Decreto $\mathrm{n}^{-0}$ 12.342, de 27 de setembro de 1978: regulamento da promoção, preservação e recuperação da saúde no campo de competência da Secretaria de Estado da Saúde (revisto e atualizado até dezembro de 1990). 5.ed. São Paulo: Imprensa Oficial do Estado, 1992. p.145-343: Decreto no 12.486, de 20 de outubro de 1978: aprova normas técnicas especiais relativas a alimentos e bebidas. 
SHEHATA, A.E.; MAGDOUB, M.N.I.; SULTAN, N.E.; EL-SAMRAGY, Y.A. Aerobic mesophilic and psychrotrophic sporeforming bacteria in buffalo milk. Journal of Dairy Science, v.66, n.6, p.1228-1231, 1983.

SILVA, E.O.T.R. e; PANETTA, J.C.; FERREIRA, F. Non-automated production of buffalo mozzarella from raw milk. Study of the microbiological contamination related to the manual and partially mechanized manufacture, São Paulo, Brazil. In: WORLD BUFFALO CONGRESS, 5., Caserta, 1997. Proceedings. Caserta: s.ed., 1997. p.259-265.

SILVA, E.O.T.R. e; PANETTA, J.C.; ISHIZUKA, M.M. Efeito microbiocida da fase de filagem, durante a fabricação de mozzarella elaborada com leite cru de búfala. Higiene Alimentar, v.13, n.59, p.28-34, 1999.

SILVA, M.C.D. da; HOFER, E.; TIBANA, A. Incidence of Listeria monocytogenes in cheese produced in Rio de Janeiro, Brazil. Journal of Food Protection, v.61, n.3, p.354-356, 1998.

SILVA, N. da; JUNQUEIRA, V.C.A.; SILVEIRA, N.F. de A. Manual de métodos de análise microbiológica de alimentos. 2.ed. São Paulo: Varela, 2001. cap.6, p.53-58: Contagem de Staphylococcus aureus.

VALLE, J.L.E. do. Queijos de massa filada. In: VAN DENDER, A.G.F. Utilização artesanal do leite de búfala. Campinas: ITAL, 1989. p.57-60. (ITAL. Manual técnico, 3)

VAN DENDER, A.G.F. Queijos. In: VAN DENDER, A.G.F. Utilização artesanal do leite de búfala. Campinas: ITAL, 1989. p.34-56. (ITAL. Manual técnico, 3) 
VAN DENDER, A.G.F.; MORENO, I.; GARCIA, S. Uso de creme de leite de búfala e de vaca na fabricação do queijo tipo mascarpone. Revista do Instituto de Laticínios Cândido Tostes, v.43, n.259, p.35-42, 1988.

VANDERZANT, C.; SPLITTSTOESSER, D. F. Compendium of methods for the microbiological examination of foods. 3.ed. Washington: American Public Health Association, 1992. 1219p.

VARNAM, A.H.; SUTHERLAND, J.P. Milk and milk products: technology, chemistry and microbiology. London: Chapman \& Hall, 1994. v.1, cap.2, p.42-100: Liquid milk and liquid milk products.

VERRUMA, M.R. Avaliação química, nutricional e sensorial do leite de búfala e derivados em comparação àqueles de leite de vaca. Piracicaba, 1993. 107p. Dissertação (Mestrado) - Escola Superior de Agricultura "Luiz de Queiroz", Universidade de São Paulo.

VERRUMA, M.R.; SALGADO, J.M. Análise química do leite de búfala em comparação ao leite de vaca. Scientia Agrícola, v.51, n.1, p.131-137, 1994.

VERRUMA, M.R.; OLIVEIRA, A.J. de; SALGADO, J.M. Avaliação química e nutricional do queijo mozzarella e iogurte de leite de búfala. Scientia Agrícola, v.50, n.3, p.438-443, 1993.

VIANNI, M. da C.E.; LÁZARO, N. dos S.; SANTANA, D.M. da N.; AFONSO, J.A.B.; MENDONÇA, C.L. de. Qualidade microbiológica do leite "in natura" de rebanhos bubalinos do Estado do Rio de Janeiro. Higiene Alimentar, v.14, n.70, p.69-72, 2000. 
VIEIRA, L.C.; LOURENÇO JÚNIOR, J. de B.; HÜHN, S. et al. Avaliação microbiológica do leite de búfalas sob diferentes práticas higiênicas. Belém: EMBRAPA, CPATU, 1994. 38p. (EMBRAPA, CPATU. Boletim de pesquisa, 155)

VIEIRA, S.D.A.; NEVES, B. dos S. Padronização do teor de gordura e do extrato seco desengordurado do leite de búfala com leite reconstituído. Revista do Instituto de Laticínios Cândido Tostes, v.35, n.208, p.27-32, 1980.

YUNES, V.M.; BENEDET, H.D. Desenvolvimento experimental de queijo fresco de leite da espécie bubalina. Ciência e Tecnologia dos Alimentos, v.20, n.3, p.285-290, 2000. 